\title{
The immune system in stroke: clinical challenges and their translation to experimental research
}

Craig J. Smith ${ }^{{ }^{*}}$, Catherine Lawrence ${ }^{2^{*}}$, Beatriz Rodriguez-Grande ${ }^{2}$, Krisztina J. Kovacs ${ }^{3}$, Jesus M. Pradillo ${ }^{2}$, Adam Denes ${ }^{2,3^{\star}}$

${ }^{1}$ Stroke and Vascular Research Centre, Institute of Cardiovascular Sciences, University of Manchester, Manchester Academic Health Science Centre, Salford Royal Foundation Trust, Salford M6 8HD, UK

${ }^{2}$ Faculty of Life Sciences, A.V. Hill Building, University of Manchester, Oxford Road, Manchester, M13 9PT, UK

${ }^{3}$ Laboratory of Molecular Neuroendocrinology, Institute of Experimental Medicine, Budapest $\mathrm{H}-1450$, Hungary

*Send correspondence to: Adam.Denes@manchester.ac.uk, catherine.lawrence@manchester.ac.uk, or Craig.Smith-2@manchester.ac.uk 


\section{Abstract}

Stroke represents an unresolved challenge for both developed and developing countries and has a huge socio-economic impact. Although considerable effort has been made to limit stroke incidence and improve outcome, strategies aimed at protecting injured neurons in the brain have all failed. This failure is likely to be due to both the incompleteness of modelling the disease and its causes in experimental research, and also the lack of understanding of how systemic mechanisms lead to an acute cerebrovascular event or contribute to outcome. Inflammation has been implicated in all forms of brain injury and it is now clear that immune mechanisms profoundly influence (and are responsible for the development of) risk and causation of stroke, and the outcome following the onset of cerebral ischemia. Until very recently, systemic inflammatory mechanisms, with respect to common comorbidities in stroke, have largely been ignored in experimental studies. The main aim is therefore to understand interactions between the immune system and brain injury in order to develop novel therapeutic approaches. Recent data from clinical and experimental research clearly show that systemic inflammatory diseases -such as atherosclerosis, obesity, diabetes or infection similar to stress and advanced age, are associated with dysregulated immune responses which can profoundly contribute to cerebrovascular inflammation and injury in the central nervous system. In this review, we summarize recent advances in the field of inflammation and stroke, focusing on the challenges of translation between pre-clinical and clinical studies, and potential anti-inflammatory/immunomodulatory therapeutic approaches.

Keywords: stroke, immune system, comorbidities, inflammation, brain injury, IL-1 


\section{Introduction}

Stroke is the second leading cause of death worldwide (Top Ten Causes of Death, 2011) and the leading cause of adult neurological disability (The Global Burden of Disease, 2004). The total number of stroke deaths is estimated at 508,000 per year in the 27 European Union members, with an annual cost of 27 billion $€$ (European cardiovascular disease statistics, 2008). Ischemic stroke, accounting for approximately $80 \%$ of all strokes, is a heterogenous and multifactorial disorder with complex interplay between environmental and genetic factors contributing to its causation, and influencing its subsequent outcome. Despite well-recognised conventional vascular risk factors (e.g. increasing age, hypertension, smoking, diabetes), stroke mechanisms (e.g. cardioembolism, artery to artery embolism, hypoperfusion) and underlying aetiologies (e.g. atherotherombosis, atrial fibrillation (AF), small vessel disease), the cause of ischemic stroke remains unclear in up to $24 \%$ of patients (Hajat et al. 2011). It is increasingly recognised that novel mechanisms may contribute not only to the pathophysiology of stroke of unknown cause, but also to that associated with conventional vascular risk factors and aetiologies of ischemic stroke. Despite many years of translational research into putative treatments for acute ischemic stroke, the only pharmacological treatments remain antiplatelet therapy for the majority (Chen et al. 2000) and thrombolysis with intravenous alteplase for selected individuals (Wardlaw et al. 2012). Prevention of stroke is based largely on management of conventional vascular risk factors, yet recurrent vascular events in stroke survivors remain frequent, despite standard secondary prevention, with $21 \%$ suffering myocardial infarction, recurrent stroke, cardiovascular death or hospitalisation for atherothrombotic events by 2 years (Venketasubramanian et al. 2011).

Prevention of stroke is therefore a massive public health challenge and major priority worldwide; and safe, effective treatments for acute ischemic stroke are urgently needed. Improving our understanding of the mechanisms causing ischemic stroke, and mediating subsequent injury and repair, are therefore crucial in developing novel therapeutic targets. The failure of so many putative therapies for ischemic stroke in bench-to-bedside research has highlighted the importance of reconsidering how translational research is approached. At a time when translational research is at a "road-block", the need to consider the realities of the clinical setting when developing experimental models of cerebral ischemia and 
undertaking pre-clinical studies has become increasingly recognised. In particular, the influence of age and comorbidities on inflammatory responses preceding, or following cerebral ischemia, has been relatively neglected in pre-clinical studies.

\section{The immune system and stroke}

Stroke is primarily, although not exclusively, a disease of the elderly. Indeed, advancing age is the single most important risk factor in stroke: in both men and women the stroke rate more than doubles for each successive 10 years after age 55 (Brown et al. 1996; Wolf et al. 1992). As activity of the immune system declines with age, the causal role of immune mechanisms in stroke pathophysiology does not seem straightforward to explain. Nevertheless, aging is associated with an elevated systemic inflammatory burden and reduced ability of cell regeneration, which contributes to diverse diseases including heart disease, cancer or stroke. In addition, the incidence of chronic inflammatory diseases appears to increase in developed countries even amongst young people, indicating that lifestyle in itself could be a major contributor to these diseases. Alterations in immune regulation seen in aged individuals, but also in young people presenting with systemic inflammation, appears to be a plausible common link between increased incidence of cardio- and cerebrovascular diseases.

Evidence indicates that inflammation is a crucial contributor to the development of all known risk factors for stroke and is also implicated in mechanisms of brain injury that occur after stroke. Stroke is a vascular disease, and major comorbidities such as atherosclerosis, hyperlipidaemia, diabetes, obesity, hypertension or infection are characterized by elevated systemic inflammatory burden, including prolonged vascular inflammation (Denes et al. 2010b; ladecola and Anrather 2011). Although much information has been accumulated over the last decades about the involvement of immune mechanisms in these diseases, experimental models of common comorbidities in stroke have been investigated in detail only recently. Current research is aiming to understand how acute and chronic inflammatory mechanisms predispose to stroke and also, how inflammation contributes to the ischemic injury itself. In experimental studies, blockade of immune processes can result in marked protection against brain injury in otherwise healthy, young animals. Inhibition of immune cells ( $T$ lymphocytes, neutrophils, etc.), proinflammatory cytokines or receptors that recognize pathogen- or damage-associated molecules can reduce infarct size in experimental rodent 
models of stroke (Denes et al. 2010b; ladecola and Anrather 2011; Denes et al. 2011b). This indicates that essential defense mechanisms, which are indispensable for protection against infectious agents, are inherent components of ischemic injury in the central nervous system (CNS). In addition, recent data show that brain injury is increased in experimental models of hypertension, diabetes, obesity, atherosclerosis or infection. Blockade of key inflammatory pathways in these models reversed brain injury induced by comorbidities after stroke, suggesting that underlying systemic inflammation indeed contributes to brain injury (Denes et al. 2010b; Denes et al. 2011b; McColl et al. 2009; Emsley et al. 2008). These results are in accordance with clinical data, showing impaired outcome in patients presenting with risk factors that involve systemic inflammation (Wolf et al. 1992; McColl et al. 2009; Emsley and Hopkins 2008a; Emsley et al. 2008; Emsley et al. 2005b). Thus, identification of major mechanisms whereby inflammation contributes to brain injury in stroke, could lead to targeted therapies in order to limit stroke incidence and improve outcome.

\section{Inflammation preceding ischemic stroke: beyond vascular risk factors?}

Advancing age and certain comorbidities, notably hypertension, stress, smoking, metabolic syndrome (including obesity) and diabetes, are themselves associated with altered or dysregulated inflammation, which may also be influenced by medications commonly used in primary and secondary prevention (e.g. antiplatelets, statins and anti-hypertensives). Inflammatory processes are considered important in the initiation and progression of atherosclerosis, plaque destabilisation and subsequent thromboembolism (Packard et al. 2009). Furthermore, emerging evidence has implicated inflammation in the pathophysiology of $\mathrm{AF}$ (Friedrichs et al. 2011) and cerebral small vessel disease (Sierra et al. 2011). Numerous epidemiological studies have investigated the association between peripheral inflammatory markers and incident cerebrovascular events in apparently healthy individuals or those with conventional risk factors (e.g. hypertension), without a previous clinical history of stroke. Of these, the most extensively studied is C-reactive protein (CRP). In a recent metaanalysis of individual participant data from 54 prospective studies, plasma CRP concentration was associated with development of incident ischemic stroke after adjusting for age and sex, although the strength of the association diminished after adjusting for conventional vascular risk factors and fibrinogen (The Emerging Risk Factors Collaboration 2010). These data imply 
that the majority of the observed association with ischemic stroke depends on age and conventional vascular risk factors. Whether such low-grade inflammation, measured by plasma CRP, has any causal role remains controversial. For example, in the JUPITER and Heart Protection Study, statins lowered both LDL-cholesterol and CRP concentrations, but the role of baseline CRP and its reduction in determining incident vascular events appear to be conflicting (Ridker et al. 2008; Heart Protection Study Collaborative Group 2011).

Lacunar infarction secondary to cerebral small vessel disease is a distinct aetiological subtype accounting for around $27 \%$ of all ischemic strokes (Hajat et al. 2011). Several studies have examined the relationships between peripheral inflammatory markers, conventional vascular risk factors and apparently asymptomatic burden and progression of cerebral small vessel disease using brain magnetic resonance imaging (MRI) white-matter hyperintensities (WMH). In the Rotterdam Scan Study, baseline plasma CRP was associated with progression of $\mathrm{WMH}$ and asymptomatic incident lacunar infarcts, after adjustment for conventional vascular risk factors and extent of carotid atherosclerosis (van Dijk et al. 2005). In a study of Japanese diabetics, soluble intercellular adhesion molecule-1 (ICAM-1) was associated with progression of WMH after adjustment for age and vascular risk factors (Umemura et al. 2011). However, in other studies, baseline plasma CRP was not associated with volume or progression of $\mathrm{WMH}$, whilst ICAM-1 was only weakly associated with progression of WMH (Markus et al. 2005; Schmidt et al. 2006; Wright et al. 2009). Such differences may reflect underlying selection bias, racial/ethnic differences, techniques for measuring $\mathrm{WMH}$ and other confounding variables such as medications.

Numerous studies have explored inflammation in human carotid atherosclerosis. In individuals without a history of stroke, plasma CRP is associated with progression of carotid atherosclerosis after adjustment for conventional vascular risk factors (Schmidt et al. 2006). Molecular imaging using ${ }^{18} \mathrm{~F}$-fluorodeoxyglucose (FDG) positron emission tomography (PET), which accumulates in macrophages, has provided insights into carotid plaque inflammation in vivo. In patients with symptomatic carotid atherosclerosis, ${ }^{18} \mathrm{FDG}$ uptake correlates with macrophage-rich areas of plaque, matrix metalloproteinase-9 (MMP-9) expression (Rudd et al. 2010; Tawakol et al. 2006; Graebe et al. 2009), distal microembolic signals and early recurrence of cerebrovascular events (Moustafa et al. 2010; Marnane et al. 2012). 
Participants in these studies tended to be receiving secondary prevention with antiplatelets and statins at the time of assessment, although the influence of vascular risk factors on these findings is unclear. A further study reported attenuation of carotid plaque ${ }^{18} \mathrm{FDG}$ uptake in individuals without history of stroke randomised to 3months de-novo treatment with simvastatin, compared with placebo (Tahara et al. 2006).

It has been proposed for many years that acute systemic infections and chronic infectious agents may play a role in the development of ischemic stroke. Several observational clinical studies have reported associations between preceding common infections (mainly respiratory tract infections) and ischemic stroke (Grau et al. 2010). The reported prevalence of preceding infection, and timing prior to index stroke varies considerably between these studies, and one study found no difference in the prevalence of recent infection between cases and controls (Paganini-Hill et al. 2003). In the largest study, based on the UK General Practice Research Database, risk of first stroke was greatest in the 3 day period following confirmed respiratory tract or urinary-tract infection (Clayton et al. 2008). Platelet activation and platelet-monocyte aggregation was exaggerated in patients presenting with stroke and recent preceding infection, compared to those without or non-stroke controls (Zeller et al. 2005). The relationship between preceding infection, conventional vascular risk factors and incident stroke subtype is unclear. One study reported no association between stroke subtype and preceding infection (Roquer et al. 2012), whilst others suggest preceding infection occurred more often in atherothromboembolic or cardioembolic infarction (Grau et al. 2010; PaganiniHill et al. 2003). However, preceding infection was associated with more severe incident strokes in multivariate analyses (Roquer et al. 2012), which is likely to influence conclusions relating to aetiological subtype. A recent case-crossover study revealed that hospitalisation with infection was associated with incident stroke, particularly within the 14 day period following admission (Elkind et al. 2011). AF is detected more frequently in hospitalised individuals with sepsis than without, and new-onset AF during sepsis is associated with inhospital incident stroke (Walkey et al. 2011). Taken together, allowing for differences in study design and methodology, the effects of bias and confounding factors, these studies suggest that common systemic infections occur frequently within the month preceding ischemic stroke. Whilst it is presumed that infections may precipitate atherothromboembolism or 
cardioembolism, our understanding of the potentially culpable organisms or mechanisms remains unclear.

Chronic infection has also been proposed to modulate the risk of ischemic stroke. Several micro-organisms, notably Chlamydia pneumonia, have received particular attention. C.pneumoniae serology is associated with incident ischemic stroke in some observational studies, but not others, but robust relationships with specific stroke subtypes are lacking (Grau et al. 2010). C.pneumoniae DNA has also been identified in carotid atheromatous plaque (Prager et al. 2002). It has been proposed that risk of stroke may be higher with exposure to multiple candidate infectious agents, the so-called concept of "infectious burden". An infectious burden index based on seropositivity of five organisms (C. pneumoniae, Helicobacter pylori, herpes simplex virus 1 and 2 and cytomegalovirus), was associated with carotid plaque thickness on ultrasound and incident stroke, after adjustment for vascular risk factors (Elkind et al. 2010b; Elkind et al. 2010a). Seropositivity for any of the organisms in isolation was not associated with incident stroke.

Therapeutic trials of antibiotics to eradicate C.pneumoniae have been disappointing. One clinical trial evaluated the effect of roxithromycin on carotid intima-to-media thickness (IMT), a marker of atherosclerosis, in individuals with a previous transient ischemic attack or minor stroke (46\% with positive C.pneumoniae serology) (Sander et al. 2004). Treatment with roxithromycin for 30 days reduced the progression of IMT in those with positive C.pneumoniae serology during the first 2 years, but not during the subsequent 2 year followup. The absence of an effect on recurrent cardiovascular events was perhaps not surprising given the limited power of the study. To date, the precise role of C.pneumoniae or other specific infectious agents in the pathophysiology of atherosclerosis and causation of stroke remains obscure.

Although some controversies exist regarding the predictive value of commonly used biomarkers and results from large clinical studies, there is a clear elevation in inflammatory mediators in all major risk factors for stroke. Atherosclerotic plaques produce various inflammatory mediators such as interleukin-1 (IL-1), or IL-6 and various immune cells, like T cells and macrophages. Elevated proinflammatory cytokines IL-1, IL-6, tumor necrosis factoralpha (TNFa) and interferon gamma (IFNY) as well as altered activation of macrophages, $\mathrm{T}$ 
cells, natural killer (NK) cells and other immune cell populations are associated with hypertension, diabetes, infection or obesity, and can also be affected by acute or chronic stress (Table 1).

\section{Inflammation and outcome following ischemic stroke}

It is now well-established that cerebral ischemia induces an inflammatory response in the brain and its vasculature, activation of neuro-endocrine pathways and a peripheral systemic inflammatory response which influences clinical outcome. Age, sex and comorbidities influence outcome following stroke and are themselves important contributors to inflammatory responses to cerebral ischemia. Advancing age and stroke severity are powerful predictors of functional outcome and survival following ischemic stroke (Weimar et al. 2004; Andersen et al. 2011). Women have a higher case fatality than men, and women survivors have worse outcomes (Di Carlo et al. 2003; Appelros et al. 2009). Diabetes and AF are predictors of mortality (Andersen et al. 2011). Infections complicating the acute phase of stroke occur in up to $30 \%$ of patients, with pneumonia and urinary tract infections accounting for up to $10 \%$ each (Westendorp et al. 2011). Pneumonia increases the risk of death three-six fold (Katzan et al. 2003; Ovbiagele and Nguyen-Huynh 2011) and likelihood of worse functional outcome or length of stay in survivors (Ovbiagele and Nguyen-Huynh 2011; Kammersgaard et al. 2001; Aslanyan et al. 2004).

In clinical studies of ischemic stroke, elucidating the complexities of CNS inflammatory responses to acute cerebral ischemia poses particular methodological challenges. Available data from in vivo imaging techniques, sampling of cerebrospinal fluid (CSF) and post-mortem studies are therefore relatively scant, based on relatively small studies in relatively selected patients. Expression of pro-inflammatory cytokines (e.g. TNF- $\alpha$ ) and adhesion molecules (e.g. ICAM-1) have been demonstrated in post-mortem human cerebral infarcts (Krupinski et al. 1994; Lindsberg et al. 1996; Sairanen et al. 2001). The pro-inflammatory cytokines IL-1ß, IL-6 and TNF- $\alpha$ are also detected in cerebrospinal fluid obtained from patients with acute ischemic stroke (Tarkowski et al. 1995; Zaremba et al. 2001). MRI based methodologies have employed systemically administered ultrasmall superparamagnetic iron oxide (USPIO) contrast to label macrophages. USPIO-enhancement of ischemic lesions in patients with 
acute ischemic stroke is heterogenous and seemingly unrelated to infarct volume or bloodbrain barrier (BBB) disruption (Saleh et al. 2004; Nighoghossian et al. 2007). [ ${ }^{11}$ C]PK11195 PET studies have demonstrated evolution of microglial activation within days of cortical/subcortical ischemic stroke, persisting for several months (Gerhard et al. 2000; Pappata et al. 2000; Radlinska et al. 2009). Using single-photon emission tomography (SPECT), radiolabelled peripheral neutrophils accumulate in cerebral ischemic lesions within hours of onset, and the extent of this accumulation is associated with infarct volume (Akopov et al. 1996; Price et al. 2004). Neutrophil recruitment to the ischemic hemisphere was confirmed histologically at post-mortem in the parenchyma and intravascular compartments (Price et al. 2004).

As inflammation in the CNS is known to modulate inflammation in the periphery, measuring peripheral systemic inflammatory responses is a far more practical approach in clinical research. Numerous studies have investigated the time-course and prognostic value of the acute-phase response and other peripheral inflammatory markers in ischemic stroke. As would be expected, these studies have been in relatively older individuals with significant prevalence of comorbidities (prior stroke or TIA $30 \%$; hypertension $45-70 \%$; diabetes $8-41 \%$; coronary artery disease 17.8-35\%) and medications at baseline (e.g. statins 56\%; antiplatelets 25\%-38\%) (Winbeck et al. 2002; Emsley et al. 2003; Ladenvall et al. 2006; Rallidis et al. 2009; Tuttolomondo et al. 2009; Whiteley et al. 2009). Cytokines expressed locally at sites of tissue inflammation, such as IL-1 and TNF- $\alpha$ are not consistently detected in plasma of patients with acute ischaemic stroke compared to controls (Tarkowski et al. 1995; Emsley et al. 2007), but plasma concentrations of other cytokines (e.g. interleukin-1 receptor antagonist (IL-1RA), IL-6), adhesion molecules (e.g. (ICAM-1, E/P-selectin) and chemokines (e.g. CXCL16) are elevated early after ischemic stroke and relate to clinical outcome (Rallidis et al. 2009; Tuttolomondo et al. 2009; Emsley et al. 2007; Vila et al. 1999; Ueland et al. 2012). The acute-phase response (APR), characterized by elevated plasma concentrations of CRP and IL-6, neutrophil leukocytosis and activation of the hypothalamic-pituitary-adrenal (HPA) axis, is induced within hours of ischemic stroke (Emsley et al. 2003). Increased serum adrenocorticotropic hormone $(\mathrm{ACTH})$ and plasma or urinary free cortisol have been reported in patients after acute ischaemic stroke (Emsley et al. 2003; Olsson 1990; Fassbender et al. 
1994). Cortisol is elevated within $4 \mathrm{~h}$ of onset of stroke, with maximal values in the first $24 \mathrm{~h}$ (Emsley et al. 2003; Fassbender et al. 1994), which is likely to reflect the magnitude of the rapid stress response to cerebral ischemia. Parameters of the APR, particularly plasma CRP, cortisol and IL-6 concentrations, correlate with stroke severity, infarct volume and worse outcome (Smith et al. 2004; Di Napoli et al. 2005; Di Napoli et al. 2001). Plasma CRP is elevated in all subtypes of ischemic stroke compared with controls, but concentrations are greatest in cardioembolic and large artery embolic stroke (Ladenvall et al. 2006) and lowest in lacunar infarcts. However, it is not clear whether these differences between subtypes are independent of stroke severity.

A key question is whether peripheral systemic inflammatory markers relate to outcome by directly contributing to evolution of infarct pathogenesis, or are simply markers of acute CNS/ peripheral inflammatory injury severity. In the acute phase of ischemic stroke, the modest correlation observed between CRP with stroke severity and infarct volume reflects its induction by upstream mediators, such as IL-1, TNF $\alpha$ and IL-6, in response to tissue injury. However, plasma CRP concentrations remain significantly elevated compared to controls even at 3 months after index stroke, particularly in large vessel disease aetiology (Emsley et al. 2003; Ladenvall et al. 2006), which may well reflect return of the APR to abnormal baseline levels indicative of ongoing vascular risk. Plasma CRP during the acute or subacute phase is associated with worse outcomes (beyond 6 months) and recurrent vascular events, independent of confounders such as age or baseline stroke severity (Whiteley et al. 2009; Di Napoli et al. 2005). CRP might therefore contribute to adverse outcome in the acute or subacute phase by directly mediating deleterious proinflammatory/thrombotic effects (e.g. activating the classical complement pathway, inducing expression of tissue factor (TF), vonWillebrand Factor (VWF), E-selectin, ICAM-1, MMP-9) (Bisoendial et al. 2005; Bisoendial et al. 2009).

The vast majority of clinical studies evaluating systemic inflammatory markers in stroke excluded patients with pre-existing infectious or inflammatory conditions, or infections complicating the acute phase, in order to limit factors confounding interpretation of the inflammatory response to stroke. However, the impact of infections should not be underestimated, and requires consideration in translational research. Several clinical factors, 
particularly stroke severity, age and dysphagia, are consistently associated with infections in stroke patients. As would be expected, the peripheral systemic inflammatory response, evidenced by plasma CRP concentrations and peripheral white-blood counts, is exaggerated in patients with infection, compared to those without (Emsley et al. 2003; Fassbender et al. 1997). In contrast to the elevated plasma concentrations of inflammatory markers in acute ischemic stroke, recent studies have demonstrated suppressed peripheral blood cellular immune responses. Induction of the cytokines IL-1, TNF- $\alpha$, IL-6, IL-10 and IL-8 by whole blood cultures stimulated with lipopolysaccharide (LPS) in vitro was significantly lower in patients with ischemic stroke than in controls (Emsley et al. 2007; Smith et al. 2012). This suppression of cytokine induction was evident in cultures obtained within hours of stroke onset, and persisted at day 5 to 7 . The magnitude of impaired cytokine induction correlated with stroke severity and with plasma cortisol concentrations, and was less pronounced in patients without infections in the acute phase (Emsley et al. 2007). Several other studies have also reported suppression of in vitro TNF induction and monocyte HLA-DR expression in acute ischemic stroke (Haeusler et al. 2008; Hug et al. 2009; Urra et al. 2009). Induction of TNF, monocyte HLA-DR expression, plasma normetanephrine and plasma cortisol concentrations in the acute phase were associated with stroke-associated infections independent of stroke severity and age (Urra et al. 2009). However, in another study, induction of TNF and monocytic HLA-DR expression were associated with incident infections, but these relationships were not independent of infarct volume (Hug et al. 2009). The clinical significance of these observations remains unclear. It has been proposed that strokeassociated immune-suppression represents enhanced susceptibility to infection in the setting of infectious challenge, although a causal relationship is yet to be established in clinical studies.

\section{Modeling risk factors and inflammatory mechanisms in stroke}

The role of the immune system in stroke, especially in cerebral ischaemia has been investigated in detail in animals (mostly rodents with middle cerebral artery occlusion (MCAo)) without apparent comorbidities. Various anti-inflammatory interventions have been shown to grant protection against brain injury, if administered within 3-6 h post-stroke. Centrally or peripherally expressed proinflammatory cytokines/chemokines such as IL-1, TNFa or 
RANTES (CCL5), proteases such as MMP-9, toll-like receptors such as TLR4 or TLR2, various immune cell populations such as T cells, macrophages, platelets or neutrophils have all been implicated in the development of ischemic brain injury, similarly to experimental models of ischaemic injury in peripheral tissues, such as myocardial infarction, kidney- or liver ischemia (Denes et al. 2010b; Denes et al. 2011b; McColl et al. 2009; Klingenberg and Hansson 2009; Dinarello 2011; Zhai et al. 2011). Although our understanding of how basic inflammatory mechanisms contribute to ischemic injury in the absence of comorbidities is far from complete, several recent review articles have addressed this issue in detail (Denes et al. 2010b; ladecola and Anrather 2011; Chamorro et al. 2012). Instead, we present some recent pre-clinical advances in translational stroke research below, highlighting the role of inflammation in some common stroke comorbidities and showing that blockade of key immune mechanisms could be therapeutically useful in experimental models of systemic inflammation and stroke.

\section{Inflammatory mechanisms in major comorbidities in stroke}

\section{Aging, atherosclerosis, diabetes and hypertension}

In experimental models, aging appears to impair outcome after experimental stroke, however, not all studies have come to the same result. Moreover, clear gender-differences are seen: estrogen (17 $\beta$-estradiol) has a protective role in young females, but exacerbates brain injury in aged female rodents, possibly via interactions with insulin-like growth factor (IGF)-1 (Liu et al. 2009; Selvamani and Sohrabji 2010a, b; Dinapoli et al. 2010; DiNapoli et al. 2008; Wang et al. 2003; Dubal and Wise 2001). Male, aged rodents often show decreased gray matter injury after experimental stroke compared to young animals, however, an increase in white matter lesions has been demonstrated (Shapira et al. 2002; Correa et al. 2011). Aging in combination with other risk factors such as obesity or atherosclerosis was found to augment inflammation and BBB injury in the brain (Pradillo et al. 2012). Aged animals express altered microglial activation, enhanced expression of proinflammatory cytokines such as IL-6, TNFa and CCL2 (Dinapoli et al. 2010), although other studies reported reduced serum IL-6 levels in response to cerebral ischemia (Liu et al. 2009). The use of different rodent models (different rat or mouse strains, embolic versus filament MCAo, animals from different age groups, etc) 
makes it currently difficult to compare existing studies and conclusively evaluate the impact of aging and the involvement of inflammatory processes in outcome after cerebral ischaemia. Diabetes impairs outcome in rodent models of focal cerebral ischemia (Bomont and MacKenzie 1995). Interestingly, brain injury and inflammation in diabetic models can be reversed by angiotensin II type 1 receptor (AT(1)-R) antagonist, PPARY agonist, administration of $17 \beta$-estradiol, IGF-1, aspirin and niacin (B3 vitamin) even at high blood glucose levels, highlighting the potential role of inflammatory mechanism in diabetes-induced exacerbation of brain injury (Kusaka et al. 2004; Toung et al. 2000; Tureyen et al. 2007; Rizk et al. 2007; Wang et al. 2009; Ye et al. 2011).

Brain injury and neurological outcome are exacerbated after cerebral ischemia in rodent models of hypertension, which can mostly (although not uniformly (Porritt et al. 2010)) be reversed by blood pressure lowering drugs (Elewa et al. 2007; Kozak et al. 2008). Nevertheless, administration of statins, ibuprofen, epidermal growth factor (EGF), or inhibition of TNFa can mediate protection against ischemic brain injury in hypertensive animals, indicating that some detrimental effects of prolonged hypertension might be explained by inflammatory mechanisms (Cole et al. 1993; Dawson et al. 1996; Hatashita et al. 1990; Yu et al. 2009; Mariucci et al. 2011).

In addition to plaque formation and focal injuries in the vasculature, atherosclerosis is now recognised as a chronic inflammatory condition. Compared to the number of studies concerning mechanisms of thrombus formation - a major contributor to cerebral ischemic events - relatively few data are available on mechanisms of brain injury in atherosclerotic animals after experimental stroke. Hyperlipidaemic ApoE-deficient mice display increased brain injury following cerebral ischemia (Laskowitz et al. 1997). When fed a high fat diet, ApoE KO mice show increased BBB injury and elevated MMP-9 expression (EIAli et al. 2011). However, ApoE has anti-inflammatory actions in the brain and therefore studies using other models of atherosclerosis are also needed to clarify the role of inflammation in brain injury mediated by atherosclerosis. Recent data show that brain inflammation is evident in high-fat fed, atherosclerotic ApoE KO mice, and in obese, atherosclerotic corpulent rats even in the absence of any acute cerebrovascular event. These inflammatory changes appear to be IL-1dependent in mice (Denes et al. 2012; Drake et al. 2011). Neuroinflammatory changes are 
also seen in patients at risk of stroke, who present with multiple risk factors for stroke and chronically elevated serum CRP, but no known neurological disease (Drake et al. 2011). Altered inflammatory parameters and increased expression of proinflammatory mediators in animal models of major risk factors for stroke show good correlation with some of the markers identified in the corresponding human disease (Table 1).

\section{Obesity/Metabolic syndrome}

Metabolic syndrome increases the risk for stroke but also other diseases including coronary artery disease and type 2 diabetes. One of the key features of metabolic syndrome is central obesity. Although being obese can result in several conditions that are associated with increased stroke risk including hypertension, diabetes and hypercholesterolaemia, obesity has now been identified as an independent risk factor for stroke (Strazzullo et al. 2010). Furthermore, being obese may lead to a worse outcome after a stroke (e.g. (Chen et al. 2012; Towfighi and Ovbiagele 2009; Whitlock et al. 2009; Zhou et al. 2008; Oki et al. 2006)). However, the reports on how obesity affects stroke in humans are contradictory, as not all studies report a relationship between obesity and increased mortality/morbidity after stroke and some studies suggest that being obese actually leads to a better outcome (Vemmos et al. 2011; Ryu et al. 2011; Olsen et al. 2008; Towfighi and Ovbiagele 2009). The reasons for this 'obesity paradox' are not understood fully but are likely to be due to a complex relationship between how obesity is measured, age, type and severity of stroke and concurrent medication (Katsnelson and Rundek 2011; Towfighi and Ovbiagele 2009). Studies have also demonstrated that obesity also leads to worse outcome after experimental stroke. The extent of ischemic damage, the incidence hemorrhagic transformation (HT) and the permeability of the BBB are exacerbated in obese rodents (McColl et al. 2010b; Terao et al. 2008; Langdon et al. 2011; Kumari et al. 2011; Park et al. 2011; Nagai et al. 2007). White matter damage has also been reported to be enhanced after experimental stroke in obese mice (Chen et al. 2011). This detrimental effect of obesity has been observed in various models of cerebral ischemia, in different species (rats, mice and gerbils) and in several models of obesity including rodents that are either genetically-obese (e.g. $o b / o b$ and $d b / d b$ mice) or made obese through a high-fat diet (DIO). 
Obesity is now considered an 'inflammatory condition' that is associated with elevated peripheral and vascular pro-inflammatory profiles (Scarpellini and Tack 2012; Sun et al. 2012) and central inflammatory changes including gliosis and activation of the cerebrovasculature in the brains of obese and high-fat fed rodents (Pistell et al. 2010; Drake et al. 2011; Thaler et al. 2012). It is generally considered that peripheral inflammation is a consequence of obesity, however, recent data suggests that central inflammation actually precedes weight gain in high-fat fed rodents (Thaler et al. 2012). Obesity-related inflammation has been shown to be responsible for some of the secondary consequences of the condition, especially insulin resistance (Dali-Youcef et al. 2012). As inflammation can strongly influence outcome following cerebral ischemia, it is possible that dysregulated inflammatory mechanisms in obesity also contribute to the poorer outcome after stroke.

In support, the central inflammatory response to stroke in obese animals appears to be compromised, and depending on the time post-reperfusion, the expression of several cytokines and activation of resident cells such as microglial is either enhanced or diminished (Zhang et al. 2004; Kumari et al. 2007; Kumari et al. 2010). Furthermore, obese mice have an exaggerated cerebrovascular inflammatory response after stroke, characterised by an increase in vascular activation and, leukocyte and platelet adhesion (Tureyen et al. 2011; Terao et al. 2008). Leukocyte adhesion to brain endothelial cells triggers endothelial signalling cascades that cause cytoskeletal alterations and tight junction disorganisation (Afonso et al. 2007). Tight junction expression (e.g. occludin) is reduced during cerebral ischaemia, an effect that is exacerbated in obese mice (Kumari et al. 2011) and could therefore contribute to the enhanced BBB breakdown after stroke observed in obesity. Cerebrovascular inflammation is associated with increased proteolytic activity, for example via the release of proteases from adherent leukocytes (Gidday et al. 2005). Substrates for these proteases include the vascular basement membrane matrix molecules (e.g. collagen-IV, laminin) and endothelial tight junction proteins (Jian and Rosenberg 2005). Endothelial cells derive mechanical and trophic support from matrix constituents via integrin receptors, and their disruption is an important contributor to BBB dysfunction (del Zoppo and Milner 2006). In particular, MMPs, especially MMP-9, have been strongly implicated in ischaemic brain pathophysiology (Zhao et al. 2007), as they contribute to the disruption of the BBB and development of HT after stroke in animals 
(Romanic et al. 1998; Rosenberg et al. 1998; Heo et al. 1999; Asahi et al. 2000) and humans (Horstmann et al. 2003; Rosell et al. 2006), via degradation of vascular matrix components. MMP expression is increased in immune cells and plasma of obese humans (Ghanim et al. 2004; Laimer et al. 2005; Glowinska-Olszewska and Urban 2007; Derosa et al. 2008a), and MMP-9 immunoreactivity is markedly increased in the brain microvasculature of ischemic tissue in obese mice (McColl et al. 2010b; Kumari et al. 2011; Chen et al. 2011). MMPs are expressed by several cell types, such as endothelial cells and neutrophils, which are the principal sources of MMP-9 after experimental and human stroke (Gidday et al. 2005). Neutrophil infiltration into the brain after experimental stroke is also increased in obese mice and rats although it is not yet known if these cells contribute to the increase in MMP-9 observed in the obese ischaemic brain. Overall, these data suggest an aggravated acute inflammatory response to stroke in obesity and a potential link between obesity and increased brain microvascular disruption. Similarly to obesity, other comorbidities are also associated with altered microvascular responses in the brain before and after stroke (Figure 1).

\section{Infection}

As outlined above, acute viral or bacterial infection in patients, mainly of the respiratory tract origin, in the week preceding stroke is associated with elevated risk of cerebral ischemia, independently of other risk factors. Preceding infection is (although not uniformly) also associated with worse clinical outcome (Emsley and Hopkins 2008a; Grau et al. 1995; Macko et al. 1996). In mice, administration of LPS prior to MCAo results in worse neurological outcome, cerebral edema and increased BBB injury (McColl et al. 2008, 2007; Denes et al. 2011a). After endotoxin treatment, blood-derived leukocytes, primarily neutrophils have been shown to contribute to BBB injury via MMP-9 production that results in altered expression of endothelial tight junction proteins (McColl et al. 2008). Endotoxin administration also results in rapid systemic upregulation of pro-inflammatory cytokines and chemokines, such as IL-1ß, TNFa, IL-6, CXCL1 (KC), RANTES (CCL5) and MCP-1 that is apparent in both the circulation and the brain prior to cerebral ischemia (Denes et al. 2011a). Thus, systemic inflammatory stimulus induced by bacterial cell wall products not only leads to activation and mobilisation of various leukocyte subsets, but also primes inflammatory responses in the brain. 
Proinflammatory cytokines, primarily IL-1, seem to be critical drivers of systemic inflammatory responses in cerebral ischaemia: intraperitoneal administration of IL-1 $\beta$ exacerbates brain injury after stroke, whereas blockade of IL-1 signalling with IL-1Ra results in protection against endotoxin-induced increase in infarct size (McColl et al. 2007).

Although LPS can be used to mimic infection by gram-negative bacteria that activate toll-like receptor-4 (TLR-4), experimental studies of infection preceding stroke have been lacking until recently. One major difficulty is to investigate how infection-induced inflammatory responses interact with mechanisms of cerebral ischemia, without affecting the course of infection and being disturbed by effects caused by the infectious organism itself. We have developed a model of gut infection prior to experimental stroke, using a parasitic nematode, Trichuris muris ( $T$. muris), which enabled polarisation of the anti-parasitic immune response towards a chronic T helper-1 (Th1) or a Th2 direction, making it possible to dissect parasite-specific effects from infection-induced inflammatory responses in cerebral ischemia. Chronic Th1-type response results in a marked exacerbation of brain injury after MCAo, which is associated with increased platelet aggregation, leukocyte recruitment and vascular injury in the brain and systemic up-regulation of a pro-inflammatory chemokine, RANTES (CCL5). Neutralisation of RANTES reversed infection-induced increase in brain injury and BBB damage without altering parasite load, indicating that inflammation in response to infection was the major contributor to brain injury. Supporting this, Th2-type polarisation of the immune response by the same parasite had no effect on stroke outcome (Denes et al. 2010a). RANTES has also been found to be increased after influenza virus infection in the circulation and the brain. Preceding influenza infection resulted in increased brain injury and BBB breakdown in a mouse permanent MCAo model (Muhammad et al. 2011), whilst MMP-9 was found to be upregulated in recruited leukocytes and microvessels in the brain both in response to both influenza and chronic T. muris infection (Muhammad et al. 2011; Denes et al. 2010a). Influenza-induced brain injury after MCAo was effectively reversed by administration of GTS21, an alpha7 nicotinic acetylcholine receptor agonists, highlighting the role of inflammatory mediators in the pathogenesis of ischemia with preceding infection (Muhammad et al. 2011). Thus, immune mechanisms induced by infection in various models appear to be the main mediators of brain injury, indicating the potential benefits of targeted anti-inflammatory 
interventions in stroke. Paradoxically, brain injury itself (seen after cerebral ischemia, subarachnoid hemorrhage or brain trauma), results in long-lasting immunosuppression that is apparent in both patients and various experimental models, leading to infectious complications that compromise survival and impair recovery (Dirnagl et al. 2007; Emsley and Hopkins 2008a). As discussed above, stroke patients often present with immune cells in the blood that show a suppressed response to inflammatory stimuli (such as bacterial endotoxin) in vitro. It is currently unclear whether post-stroke immunosuppression exerts any beneficial effects via dampening harmful inflammatory mechanisms after acute cerebrovascular events. Nevertheless, the negative impact of infectious complications on outcome in stroke patients highlights the key role of a functional immune system in limiting the spread of opportunistic pathogens even if some of these essential inflammatory mechanisms could be causing additional injury in the CNS. Thus, deeper understanding of infection-induced inflammatory mechanisms after stroke could be crucial for targeted therapies in order to limit the side effects of any anti-inflammatory interventions. Nevertheless, animal models of infection and systemic inflammation suggest a functional role for inflammation in impaired outcome after stroke, which appears to be similar to other models of comorbidities like hypertension, diabetes, obesity or stress (Table 2).

\section{Stress}

Life time stress is generally held as a major risk- and complicating factor in various neurological diseases including stroke (Herman 2012). Exposure to acute or chronic stressors increases the vulnerability to the disease and/or exacerbates stroke damage (Surtees et al. 2008; Hankey 2006). Exposure to various stressors results in several physiological and pathophysiological changes in the periphery as well as in the CNS that may contribute to the damage. Stress-induced autonomic arousal contributes to various cardiovascular- (high blood pressure, increased heart rate) and metabolic alterations that are acknowledged independent risk factors for stroke. It has been shown recently that stress augments insulin resistance and evokes inflammation to increase coagulation factors through adipose tissue derived MCP-1 (Uchida et al. 2012).

There might be several potential cellular mechanisms through which stress pathophysiology underlie stress-stroke interaction ranging from impairment of neurogenesis 
(McEwen 2000; Banasr and Duman 2007) to exacerbation of neuroinflammation (Munhoz et al. 2008) and activation of HPA axis in response to proinflammatory mediators (Ericsson et al. 1994; Kovacs and Elenkov 1995).

Similarly to LPS, cellular stressors (such as UV, osmotic, hypoxia and hypoglycemia) also converge onto MyD88/NFkB/MAPK pathways to provide the means how cellular insults aggravate neuroinflammation (Munhoz et al. 2010). However, it remains unknown how systemic challenges are translated to cellular stress effects.

Stress results in innate immune "arousal" in the brain (Fleshner et al. 2002; Fleshner 2012) by priming and activating microglia and astrocytes (Sugama et al. 2007). Stressinduced arousal of glia may result in increased synthesis and release of cytokines such as IL$1 \alpha$ and IL-1 $\beta$, TNF $\alpha$ and IL-6 along with up-regulation of iNOS and COX2. At the cellular level, it is very likely that systemic stress provokes "sterile inflammation" via expression of danger-associated molecular patterns (DAMPs) especially alarmins that potentiate neuroinflammatory changes that occur in the neurovascular unit during stroke. It is becoming increasingly evident that stress- level glucocorticoids are proinflammatory in the cortex and corticosterone potentiates LPS-induced proinflammatory cytokines, IL-1 $\beta$ and TNF $\alpha$ via NFkB activation (Munhoz et al. 2010).

Chronic stress also results in endothelial dysfunction, impaired endothelium dependent vasodilatation, increased superoxide production and reduced brain endothelial NOS levels. These changes are likely to contribute to stroke vulnerability mediated by stress-induced corticosteroids, since glucocorticoid receptor antagonist RU38486 (mifepristone) completely reversed these deleterious endothelial effects (Balkaya et al. 2011).

Subchronic stress results in "leaky gut" and bacterial LPS of invading bacteria triggers the TLR-4 pathway, activates NFkB and releases proinflammatory cytokines (IL-6) and proinflammatory mediators (COX2, iNOS) (Garate et al. 2012), thus contributing to the stressinduced immune priming. Indeed, stress-induced colonic bacterial transfer has been implicated as one of the possible mechanisms through which stress worsens stroke outcome (Caso et al. 2009).

IL-1 $\beta$ is highly expressed within the brain in response to stress and/or injury. IL-1 acts on glia via the NFKB pathway to exacerbate local inflammatory responses and affects 
hypothalamic and cortical neurons by regulating CREB activity via p38 MAPK signalling, thus coordinating adaptive neuronal responses to stress and injury (Srinivasan et al. 2004). In parallel, social stress suppresses cell protective and pro-survival mechanisms, such as Bcl-2 expression (DeVries et al. 2001) and exacerbates stroke.

Cortisol in humans, and corticosterone in rodents, are major glucocorticoid hormones released by the adrenals during systemic stress. Synthetic glucocorticoids are widely used in clinical neurology to control CNS inflammation, yet there is no evidence that exogenous corticosteroids are beneficial, and may even be harmful, in acute stroke patients (Sandercock and Soane 2011). Although corticosteroids were long held as anti-inflammatory, recent evidence (Dinkel et al. 2003) suggest that the context of glucocorticoid exposure is important in determining how corticosteroids will affect inflammation and, consequently, stroke injury. Whether glucocorticoid hormones increase or decrease CNS inflammation depends on the dose, timing and duration of the steroid exposure as well as on the type of glucocorticoids administered. The immunosuppressive effect of glucocorticoids originates from the observed leukopenia following application of synthetic hormone (dexamethasone) in pharmacological doses. In contrast, substantial evidence indicates that in an acute alarm situation, stressinduced glucocorticoids redirect leukocytes from the systemic circulation to the place of the injury and thus play a dramatic role in leukocyte trafficking that may also have an important impact in stroke-damage. While basal level of glucocorticoids are required for the immune activation (permissive effect), stress-induced corticosteroid elevation stimulates cellular immune response (acute effect), brief glucocorticoid exposure enhances immune responses to subsequent inflammatory insults (priming effect) and chronic exposure to very high steroid doses are immunosuppressive (Sorrells and Sapolsky 2007; Sorrells et al. 2009). Furthermore, microglia express glucocorticoid receptors, which provide direct means through which stress-induced corticosteroids increase microglia proliferation and induce their inflammatory phenotype (Nair and Bonneau 2006).

Finally, proinflammatory cytokines that are released in the periphery in stroke subjects, like other stressors, are able to activate the final arm of the HPA axis to start a reverberating cycle to even further worsen the outcome of the injury. Furthermore, post-stroke stress- 
arousal of the sympathetic nervous system induces depression of the cell mediated immunity that may increase vulnerability to post-stroke infectious complications (Selmeczy et al. 2008).

\section{IL-Ra as a candidate treatment for acute cerebral ischemia: experimental and clinical evidence}

Only a few inflammatory mechanisms that have proved to contribute to outcome in experimental models of comorbidities in stroke have been tested in humans. As outlined above, IL-1 has been implicated in the pathogenesis of several risk factors for stroke, and is a major driver of ischemic brain injury (Allan et al. 2005). IL-Ra is a naturally expressed protein and a reversible, competitive inhibitor of IL-1 actions with high selectivity. During the last fifteen years, IL-1Ra has been tested experimentally in rodents using different models of cerebral ischemia, different routes of administration (peripherally or centrally) and at different time points: before or at the time of stroke, and at the beginning or at $3 \mathrm{~h}$ of reperfusion (Garcia et al. 1995; Stroemer and Rothwell 1997; Mulcahy et al. 2003). IL-1Ra has been shown to be neuroprotective by reducing the number of necrotic neurons, infarct volume and improving overall outcome. Endogenous IL-1Ra is upregulated after cerebral ischemia, but it is likely to be insufficient to fully prevent IL-1 actions (Pinteaux et al. 2006; Denes et al. 2008). Subcutaneous administration of a single dose of IL-1Ra reduced brain injury and resulted in sustained high concentrations in the plasma and the CSF, penetrated into areas of BBB disruption and co-localized with viable neurons (Greenhalgh et al. 2010). In accordance with the STAIR guidelines it is imperative to test candidate drugs in aged and co-morbid animals, to use clinically relevant administration routes and techniques to facilitate the translation from 'bench to bedside'. With this in mind, the effect of subcutaneous administration of IL-1Ra has been tested at clinically relevant time points after experimental stroke to aged and co-morbid animals. Corpulent rats that are homozygous for the autosomal recessive $\mathrm{cp}$ gene (cp/cp) and spontaneously develop obesity, hyperlipidemia, insulin resistance, glomerular sclerosis, and atherosclerosis with enhanced vascular contractility and reduced vascular relaxation have been used for this study (Mangat et al. 2007). Peripheral administration of IL-1Ra at the time of reperfusion or with $3 \mathrm{~h}$ delay to aged lean and $\mathrm{Cp}$ rats, reduces ischemic brain injury, BBB breakdown, microglial activation, neutrophil infiltration and expression of MMP-9 and IL-6, 
which provides further supporting evidence for IL-1Ra as a lead candidate for the treatment of ischemic stroke (Pradillo et al. 2012).

In a phase II randomised, placebo-controlled trial of intravenous IL-1Ra in patients presenting within $6 \mathrm{~h}$ of onset of stroke symptoms, concentrations of plasma IL-6, CRP and neutrophil leukocytosis were markedly reduced during the first 5-7d in patients receiving IL-1Ra (Emsley et al. 2005a). No serious adverse events were attributed to test treatment and more patients randomised to IL-1Ra achieved a favourable outcome at 3 months in exploratory analyses. These data suggest IL-Ra is safe, well-tolerated and reduces parameters of peripheral inflammation which are known to correlate with stroke severity, infarct volume and poor outcome, by blocking induction by IL-1-mediated pathways. In secondary analyses, the effects of IL-Ra on ex vivo blood cytokine induction were evaluated (Smith et al. 2012). Induction of TNF- $\alpha$, IL-1 $\beta$, IL-6, IL-8 and IL-10 by LPS was significantly reduced in patients at admission, prior to receiving IL-1Ra or placebo, compared to controls without stroke. At $24 \mathrm{~h}$ and day 5-7, cytokine induction remained suppressed in the placebo group, whilst in those treated with IL-1Ra induction of TNF- $\alpha$ and IL-1 was significantly greater. Plasma cortisol concentrations, elevated at admission in patients compared to controls, were substantially reduced at $24 \mathrm{~h}$ in the patients receiving IL-1Ra and inversely correlated with either TNF- $\alpha$ or IL-1 $\beta$ induction at admission. The mechanisms underlying this apparent reversal of peripheral innate immune suppression by IL-1Ra remain unclear. It is well recognized that corticosteroids exert potent suppressive effects on monocyte cytokine induction. One plausible explanation is therefore that IL-1Ra reverses innate immune suppression by blocking IL-1-induced pathways involved in augmenting HPA axis activity. The clinical relevance of these observations on incident infections and clinical outcome in patients is also unresolved. It is possible that reversal of peripheral immune suppression by IL-Ra may reduce susceptibility to infection in the acute phase of stroke, which might therefore improve clinical outcomes. A similar number of infections occurred in the IL-Ra and placebo groups during the acute phase, but interpretation is limited by the small study size. Large-scale studies are required to determine the effects of treatment with IL-1Ra on incident infection and clinical outcome, particularly when considering the influence of other confounding factors. 


\section{Conclusions}

Inflammatory mechanisms contribute to all major comorbidities in ischemic stroke, and inflammation is a key driver of ischemic brain injury and repair even in the absence of comorbidities. Modulating immune and inflammatory pathways therefore offers considerable potential for stroke prevention and improving outcome following stroke. However, many complex factors need to be considered in successfully developing such therapies from bench to bedside. A fundamental challenge to address is the balance between pro- and antiinflammatory pathways in determining risk and outcome, in the clinical setting of advanced age, comorbidities (including infections) and medications already used in standard care. Therapies targeting immune/ inflammatory pathways have several potential advantages. Blocking deleterious pro-inflammatory pathways might enable more prolonged time-windows for administration in the acute phase of ischemic stroke, and augment beneficial effects of thrombolysis by protecting reperfused penumbra and reducing reperfusion injury/haemorrhagic transformation. As inflammation is also implicated in haemorrhagic stroke, anti-inflammatory agents may offer novel therapeutic opportunities in intracerebral and subarachnoid haemorrhage. By contrast, prolonged blockade of pro-inflammatory pathways may also have detrimental effects on outcome in different stroke subtypes. A key consideration is the effect this may have on the transition to potentially beneficial antiinflammatory or reparative pathways. Previous clinical trials of immune-modulating therapies have already provided cautionary tales. In the Enlimomab Acute Stroke Trial, a randomised controlled trial of a murine monoclonal antibody to ICAM-1 (Enlimomab investigators, 2001), the enlimomab-treated patients had significantly worse outcomes, and a higher incidence of fever, infections and death. Whilst this has been attributed mainly to adverse immunoactivation precipitated by administration of murine antibody, this highlights the importance of considering the impact of blocking innate responses that are also crucial in host defence to infection.

Using appropriate animal models of stroke, which attempt to incorporate the complexities of the clinical setting, is an essential component of drug development acknowledged by international consensus (Fisher et al. 2009).To facilitate translation, animal models will need to account for central and systemic effects of anaesthesia and surgical stress. Experimental 
settings incorporating comorbidities (aging, infection, atherosclerosis, etc) and delayed assessment of outcome with particular impact on recovery/regeneration will likely yield clinically relevant data. Even so, it is not possible to consider all aspects of the clinical setting in pre-clinical modelling (e.g. exposure of patients to a wide array of medicines, differences in life span and main physiological parameters compared with rodents). Therefore, it is vital that experimental models are continuously monitored for their translational value and their limitations are carefully considered.

\section{Conflict of interest}

The authors declare that they have no conflict of interest. 


\section{References}

Afonso PV, Ozden S, Prevost MC, Schmitt C, Seilhean D, Weksler B, Couraud PO, Gessain A, Romero IA, Ceccaldi PE (2007) Human blood-brain barrier disruption by retroviralinfected lymphocytes: role of myosin light chain kinase in endothelial tight-junction disorganization. Jlmmunol 179 (4):2576-2583

Akopov SE, Simonian NA, Grigorian GS (1996) Dynamics of polymorphonuclear leukocyte accumulation in acute cerebral infarction and their correlation with brain tissue damage. Stroke; a journal of cerebral circulation 27 (10):1739-1743

Allan SM, Tyrrell PJ, Rothwell NJ (2005) Interleukin-1 and neuronal injury. Nat Rev Immunol 5 (8):629-640

Andaluz-Ojeda D, Iglesias V, Bobillo F, Almansa R, Rico L, Gandia F, Loma AM, Nieto C, Diego R, Ramos E, Nocito M, Resino S, Eiros J, Tamayo E, de Lejarazu R, BermejoMartin J (2011) Early natural killer cell counts in blood predict mortality in severe sepsis. Critical Care 15 (5):R243

Andersen KK, Andersen ZJ, Olsen TS (2011) Predictors of early and late case-fatality in a nationwide Danish study of 26,818 patients with first-ever ischemic stroke. Stroke; a $\begin{array}{llll}\text { journal of cerebral circulation } 42 & \text { (10):2806-2812. }\end{array}$ doi:10.1161/STROKEAHA.111.619049

Appelros P, Stegmayr B, Terent A (2009) Sex differences in stroke epidemiology: a systematic review. Stroke; a journal of cerebral circulation 40 (4):1082-1090. doi:10.1161/STROKEAHA.108.540781

Asahi M, Asahi K, Jung JC, del Zoppo GJ, Fini ME, Lo EH (2000) Role for matrix metalloproteinase 9 after focal cerebral ischemia: effects of gene knockout and enzyme inhibition with BB-94. JCerebBlood Flow Metab 20 (12):1681-1689

Aslanyan S, Weir CJ, Diener HC, Kaste M, Lees KR (2004) Pneumonia and urinary tract infection after acute ischaemic stroke: a tertiary analysis of the GAIN International trial. European journal of neurology : the official journal of the European Federation of Neurological Societies 11 (1):49-53

Balkaya M, Prinz V, Custodis F, Gertz K, Kronenberg G, Kroeber J, Fink K, Plehm R, Gass P, Laufs U, Endres M (2011) Stress Worsens Endothelial Function and Ischemic Stroke via Glucocorticoids. Stroke; a journal of cerebral circulation 42 (11):3258-3264. doi:10.1161/strokeaha.110.607705

Banasr M, Duman RS (2007) Regulation of neurogenesis and gliogenesis by stress and antidepressant treatment. CNS Neurol Disord Drug Targets 6 (5):311-320

Barath P, Fishbein MC, Cao J, Berenson J, Helfant RH, Forrester JS (1990) Detection and localization of tumor necrosis factor in human atheroma. The American Journal of Cardiology 65 (5):297-302 
Baybutt HN, Holsboer F (1990) Inhibition of Macrophage Differentiation and Function by Cortisol. Endocrinology 127 (1):476-480. doi:10.1210/endo-127-1-476

Bisoendial RJ, Birjmohun RS, Akdim F, van 't Veer C, Spek CA, Hartman D, de Groot ER, Bankaitis-Davis DM, Kastelein JJ, Stroes ES (2009) C-reactive protein elicits white blood cell activation in humans. The American journal of medicine 122 (6):582 e581589. doi:10.1016/j.amjmed.2008.11.032

Bisoendial RJ, Kastelein JJ, Levels JH, Zwaginga JJ, van den Bogaard B, Reitsma PH, Meijers JC, Hartman D, Levi M, Stroes ES (2005) Activation of inflammation and coagulation after infusion of C-reactive protein in humans. Circ Res 96 (7):714-716. doi:10.1161/01.RES.0000163015.67711.AB

Bomont L, MacKenzie ET (1995) Neuroprotection after focal cerebral ischaemia in hyperglycaemic and diabetic rats. Neuroscience letters 197 (1):53-56

Bousser M-G (2012) Stroke prevention: an update. Frontiers of Medicine 6 (1):22-34

Bradshaw EM, Raddassi K, Elyaman W, Orban T, Gottlieb PA, Kent SC, Hafler DA (2009) Monocytes from Patients with Type 1 Diabetes Spontaneously Secrete Proinflammatory Cytokines Inducing Th17 Cells. The Journal of Immunology 183 (7):4432-4439. doi:10.4049/jimmunol.0900576

Brandes RP, Fleming I, Busse R (2005) Endothelial aging. Cardiovascular Research 66 (2):286-294. doi:10.1016/j.cardiores.2004.12.027

Brown RD, Whisnant JP, Sicks JD, O'Fallon WM, Wiebers DO (1996) Stroke incidence, prevalence, and survival: secular trends in Rochester, Minnesota, through 1989. Stroke; a journal of cerebral circulation 27 (3):373-380

Calderon B, Suri A, Unanue ER (2006) In CD4+ T-Cell-Induced Diabetes, Macrophages Are the Final Effector Cells that Mediate Islet $\hat{I}^{2}$-Cell Killing: Studies from an Acute Model. The American Journal of Pathology 169 (6):2137-2147

Caso JR, Hurtado O, Pereira MP, Garcia-Bueno B, Menchen L, Alou L, Gomez-Lus ML, Moro MA, Lizasoain I, Leza JC (2009) Colonic bacterial translocation as a possible factor in stress-worsening experimental stroke outcome. American journal of physiology Regulatory, integrative and comparative physiology 296 (4):R979-985

Caso JR, Lizasoain I, Lorenzo P, Moro MA, Leza JC (2006) The role of tumor necrosis factoralpha in stress-induced worsening of cerebral ischemia in rats. Neuroscience 142 (1):59-69. doi:10.1016/j.neuroscience.2006.06.009

Celi A, Cianchetti S, Dell'Omo G, Pedrinelli R (2010) Angiotensin II, tissue factor and the thrombotic paradox of hypertension. Expert review of cardiovascular therapy 8 (12):1723-1729

Chae CU, Lee RT, Rifai N, Ridker PM (2001) Blood Pressure and Inflammation in Apparently Healthy Men. Hypertension 38 (3):399-403. doi:10.1161/01.hyp.38.3.399

Chamorro A, Meisel A, Planas AM, Urra X, van de Beek D, Veltkamp R (2012) The immunology of acute stroke. Nature reviews Neurology 8 (7):401-410. doi:10.1038/nrneurol.2012.98 
Chen J, Cui X, Zacharek A, Cui Y, Roberts C, Chopp M (2011) White matter damage and the effect of matrix metalloproteinases in type 2 diabetic mice after stroke. Stroke; a journal of cerebral circulation 42 (2):445-452

Chen Z, Yang G, Offer A, Zhou M, Smith M, Peto R, Ge H, Yang L, Whitlock G (2012) Body mass index and mortality in China: a 15-year prospective study of 220000 men. Int J Epidemiol 41 (2):472-481

Chen ZM, Sandercock P, Pan HC, Counsell C, Collins R, Liu LS, Xie JX, Warlow C, Peto R (2000) Indications for early aspirin use in acute ischemic stroke : A combined analysis of 40000 randomized patients from the chinese acute stroke trial and the international stroke trial. On behalf of the CAST and IST collaborative groups. Stroke; a journal of cerebral circulation 31 (6):1240-1249

Clayton TC, Thompson M, Meade TW (2008) Recent respiratory infection and risk of cardiovascular disease: case-control study through a general practice database. European heart journal 29 (1):96-103. doi:10.1093/eurheartj/ehm516

Coe CL, Rosenberg LT, Levine S (1988) Effect of Maternal Separation on the Complement System and Antibody Responses in Infant Primates. International Journal of Neuroscience 40 (3-4):289-302. doi:doi:10.3109/00207458808990717

Cole DJ, Patel PM, Reynolds L, Drummond JC, Marcantonio S (1993) Temporary focal cerebral ischemia in spontaneously hypertensive rats: the effect of ibuprofen on infarct volume. The Journal of pharmacology and experimental therapeutics 266 (3):1713-1717

Correa F, Gauberti M, Parcq J, Macrez R, Hommet Y, Obiang P, Hernangomez M, Montagne A, Liot G, Guaza C, Maubert E, Ali C, Vivien D, Docagne F (2011) Tissue plasminogen activator prevents white matter damage following stroke. The Journal of experimental medicine 208 (6):1229-1242. doi:10.1084/jem.20101880

Dalekos GN, Elisaf M, Bairaktari E, Tsolas O, Siamopoulos KC (1997) Increased serum levels of interleukin-1 $\beta$ in the systemic circulation of patients with essential hypertension: Additional risk factor for atherogenesis in hypertensive patients? Journal of Laboratory and Clinical Medicine 129 (3):300-308

Dali-Youcef N, Mecili M, Ricci R, Andres E (2012) Metabolic inflammation: Connecting obesity and insulin resistance. Annals of medicine

Dawson DA, Martin D, Hallenbeck JM (1996) Inhibition of tumor necrosis factor-alpha reduces focal cerebral ischemic injury in the spontaneously hypertensive rat. Neuroscience letters $218(1): 41-44$

del Zoppo GJ, Milner R (2006) Integrin-matrix interactions in the cerebral microvasculature. ArteriosclerThrombVascBiol 26 (9):1966-1975

Denes A, Drake C, Stordy J, Chamberlain J, McColl BW, Gram H, Crossman D, Francis S, Allan SM, Rothwell NJ (2012) Interleukin-1 mediates neuroinflammatory changes associated with diet-induced atherosclerosis. Journal of the American Heart Association 1 (3):e002006. doi:10.1161/JAHA.112.002006 
Denes A, Ferenczi S, Halasz J, Kornyei Z, Kovacs KJ (2008) Role of CX3CR1 (fractalkine receptor) in brain damage and inflammation induced by focal cerebral ischemia in mouse. Journal of cerebral blood flow and metabolism : official journal of the International Society of Cerebral Blood Flow and Metabolism 28 (10):1707-1721

Denes A, Ferenczi S, Kovacs KJ (2011a) Systemic inflammatory challenges compromise survival after experimental stroke via augmenting brain inflammation, blood- brain barrier damage and brain oedema independently of infarct size. Journal of neuroinflammation 8:164. doi:10.1186/1742-2094-8-164

Denes A, Humphreys N, Lane TE, Grencis R, Rothwell N (2010a) Chronic systemic infection exacerbates ischemic brain damage via a CCL5 (regulated on activation, normal Tcell expressed and secreted)-mediated proinflammatory response in mice. The Journal of neuroscience : the official journal of the Society for Neuroscience 30 (30):10086-10095. doi:10.1523/JNEUROSCI.1227-10.2010

Denes A, Pinteaux E, Rothwell NJ, Allan SM (2011b) Interleukin-1 and stroke: biomarker, harbinger of damage, and therapeutic target. Cerebrovasc Dis 32 (6):517-527. doi:10.1159/000332205

Denes A, Thornton P, Rothwell NJ, Allan SM (2010b) Inflammation and brain injury: acute cerebral ischaemia, peripheral and central inflammation. Brain, behavior, and immunity 24 (5):708-723. doi:10.1016/j.bbi.2009.09.010

Derosa G, Ferrari I, D'Angelo A, Tinelli C, Salvadeo SA, Ciccarelli L, Piccinni MN, Gravina A, Ramondetti F, Maffioli P, Cicero AF (2008a) Matrix metalloproteinase-2 and -9 levels in obese patients. Endothelium 15 (4):219-224

Derosa G, Ferrari I, D'Angelo A, Tinelli C, Salvadeo SAT, Ciccarelli L, Piccinni MN, Gravina A, Ramondetti F, Maffioli P, Cicero AFG (2008b) Matrix Metalloproteinase-2 and -9 Levels in Obese Patients. Endothelium 15 (4):219-224

DeVries AC, Joh HD, Bernard O, Hattori K, Hurn PD, Traystman RJ, Alkayed NJ (2001) Social stress exacerbates stroke outcome by suppressing $\mathrm{Bcl}-2$ expression. Proceedings of the National Academy of Sciences of the United States of America 98 (20):11824-11828. doi:10.1073/pnas.201215298

Di Carlo A, Lamassa M, Baldereschi M, Pracucci G, Basile AM, Wolfe CD, Giroud M, Rudd A, Ghetti A, Inzitari D (2003) Sex differences in the clinical presentation, resource use, and 3-month outcome of acute stroke in Europe: data from a multicenter multinational hospital-based registry. Stroke; a journal of cerebral circulation 34 (5):1114-1119. doi:10.1161/01.STR.0000068410.07397.D7

Di Napoli M, Papa F, Bocola V (2001) C-reactive protein in ischemic stroke: an independent prognostic factor. Stroke; a journal of cerebral circulation 32 (4):917-924

Di Napoli M, Schwaninger M, Cappelli R, Ceccarelli E, Di Gianfilippo G, Donati C, Emsley HC, Forconi S, Hopkins SJ, Masotti L, Muir KW, Paciucci A, Papa F, Roncacci S, Sander D, Sander K, Smith CJ, Stefanini A, Weber D (2005) Evaluation of C-reactive protein measurement for assessing the risk and prognosis in ischemic stroke: a statement for 
health care professionals from the CRP Pooling Project members. Stroke; a journal of cerebral circulation 36 (6):1316-1329. doi:10.1161/01.STR.0000165929.78756.ed

Dinapoli VA, Benkovic SA, Li X, Kelly KA, Miller DB, Rosen CL, Huber JD, O'Callaghan JP (2010) Age exaggerates proinflammatory cytokine signaling and truncates signal transducers and activators of transcription 3 signaling following ischemic stroke in the rat. Neuroscience 170 (2):633-644. doi:10.1016/j.neuroscience.2010.07.011

DiNapoli VA, Huber JD, Houser K, Li X, Rosen CL (2008) Early disruptions of the blood-brain barrier may contribute to exacerbated neuronal damage and prolonged functional recovery following stroke in aged rats. Neurobiology of aging 29 (5):753-764. doi:10.1016/j.neurobiolaging.2006.12.007

Dinarello CA (2011) Interleukin-1 in the pathogenesis and treatment of inflammatory diseases. Blood 117 (14):3720-3732. doi:10.1182/blood-2010-07-273417

Dinkel K, MacPherson A, Sapolsky RM (2003) Novel glucocorticoid effects on acute inflammation in the CNS. Journal of neurochemistry 84 (4):705-716

Dirnagl U, Klehmet J, Braun JS, Harms H, Meisel C, Ziemssen T, Prass K, Meisel A (2007) Stroke-induced immunodepression: experimental evidence and clinical relevance. Stroke; a journal of cerebral circulation 38 (2 Suppl):770-773. doi:10.1161/01.STR.0000251441.89665.bc

Dong ZM, Wagner DD (1998) Leukocyte-endothelium adhesion molecules in atherosclerosis. Journal of Laboratory and Clinical Medicine 132 (5):369-375

Drake C, Boutin H, Jones MS, Denes A, McColl BW, Selvarajah JR, Hulme S, Georgiou RF, Hinz R, Gerhard A, Vail A, Prenant C, Julyan P, Maroy R, Brown G, Smigova A, Herholz K, Kassiou M, Crossman D, Francis S, Proctor SD, Russell JC, Hopkins SJ, Tyrrell PJ, Rothwell NJ, Allan SM (2011) Brain inflammation is induced by comorbidities and risk factors for stroke. Brain, behavior, and immunity 25 (6):11131122

Du Q, Min S, Chen L-Y, Ma Y-D, Guo X-L, Wang Z, Wang Z-G (2012) Major Stress Hormones Suppress the Response of Macrophages Through Down-Regulation of TLR2 and TLR4. Journal of Surgical Research 173 (2):354-361

Dubal DB, Wise PM (2001) Neuroprotective effects of estradiol in middle-aged female rats. Endocrinology $142(1): 43-48$

Duffaut C, Zakaroff-Girard A, Bourlier V, Decaunes P, Maumus M, Chiotasso P, Sengenes C, Lafontan M, Galitzky J, Bouloumie A (2009) Interplay Between Human Adipocytes and T Lymphocytes in Obesity. Arteriosclerosis, Thrombosis, and Vascular Biology 29 (10):1608-1614. doi:10.1161/atvbaha.109.192583

Dziewas R, Ritter M, Usta N, Boentert M, Hor H, Dittrich R, SchÃabitz WR, Ringelstein EB, Young $P$ (2007) Atherosclerosis and Obstructive Sleep Apnea in Patients with Ischemic Stroke. Cerebrovascular Diseases 24 (1):122-126

Egido JA, Castillo O, Roig B, Sanz I, Herrero MR, Garay MT, Garcia AM, Fuentes M, Fernandez C (2012) Is psycho-physical stress a risk factor for stroke? A case-control 
study. Journal of neurology, neurosurgery and psychiatry 83 (11):1104-1111. doi:10.1136/jnnp-2012-302420

EIAli A, Doeppner TR, Zechariah A, Hermann DM (2011) Increased blood-brain barrier permeability and brain edema after focal cerebral ischemia induced by hyperlipidemia: role of lipid peroxidation and calpain-1/2, matrix metalloproteinase2/9, and RhoA overactivation. Stroke; a journal of cerebral circulation 42 (11):32383244. doi:10.1161/STROKEAHA.111.615559

Elewa HF, Kozak A, Johnson MH, Ergul A, Fagan SC (2007) Blood pressure lowering after experimental cerebral ischemia provides neurovascular protection. Journal of hypertension 25 (4):855-859. doi:10.1097/HJH.0b013e3280149708

Elkind MS, Carty CL, O'Meara ES, Lumley T, Lefkowitz D, Kronmal RA, Longstreth WT, Jr. (2011) Hospitalization for infection and risk of acute ischemic stroke: the Cardiovascular Health Study. Stroke; a journal of cerebral circulation 42 (7):18511856. doi:10.1161/STROKEAHA. 110.608588

Elkind MS, Luna JM, Moon YP, Boden-Albala B, Liu KM, Spitalnik S, Rundek T, Sacco RL, Paik MC (2010a) Infectious burden and carotid plaque thickness: the northern Manhattan study. Stroke; a journal of cerebral circulation 41 (3):e117-122. doi:10.1161/STROKEAHA.109.571299

Elkind MS, Ramakrishnan P, Moon YP, Boden-Albala B, Liu KM, Spitalnik SL, Rundek T, Sacco RL, Paik MC (2010b) Infectious burden and risk of stroke: the northern $\begin{array}{lllll}\text { Manhattan study. Archives of neurology } 67 & \text { (1):33-38. }\end{array}$ doi:10.1001/archneurol.2009.271

Emsley HC, Hopkins SJ (2008a) Acute ischaemic stroke and infection: recent and emerging concepts. Lancet neurology 7 (4):341-353. doi:10.1016/S1474-4422(08)70061-9

Emsley HC, Smith CJ, Gavin CM, Georgiou RF, Vail A, Barberan EM, Hallenbeck JM, del Zoppo GJ, Rothwell NJ, Tyrrell PJ, Hopkins SJ (2003) An early and sustained peripheral inflammatory response in acute ischaemic stroke: relationships with infection and atherosclerosis. Journal of neuroimmunology 139 (1-2):93-101

Emsley HC, Smith CJ, Gavin CM, Georgiou RF, Vail A, Barberan EM, Illingworth K, Scarth S, Wickramasinghe V, Hoadley ME, Rothwell NJ, Tyrrell PJ, Hopkins SJ (2007) Clinical outcome following acute ischaemic stroke relates to both activation and autoregulatory inhibition of cytokine production. BMC neurology 7:5. doi:10.1186/1471-2377-7-5

Emsley HC, Smith CJ, Georgiou RF, Vail A, Hopkins SJ, Rothwell NJ, Tyrrell PJ (2005a) A randomised phase II study of interleukin-1 receptor antagonist in acute stroke patients. Journal of neurology, neurosurgery, and psychiatry 76 (10):1366-1372. doi:10.1136/jnnp.2004.054882

Emsley HC, Smith CJ, Georgiou RF, Vail A, Tyrrell PJ, Barberan EM, Rothwell NJ, Hopkins SJ (2005b) Correlation of systemic inflammatory response with infarct volume in 
acute ischemic stroke patients. Stroke; a journal of cerebral circulation 36 (2):228229; author reply 228-229. doi:10.1161/01.STR.0000155197.88944.ac

Emsley HC, Smith CJ, Tyrrell PJ, Hopkins SJ (2008) Inflammation in acute ischemic stroke and its relevance to stroke critical care. Neurocritical care 9 (1):125-138. doi:10.1007/s12028-007-9035-x

Emsley HCA, Hopkins SJ (2008b) Acute ischaemic stroke and infection: recent and emerging concepts. The Lancet Neurology 7 (4):341-353

Enlimomab Acute Stroke Trial Investigators (2001) Use of anti-ICAM-1 therapy in ischemic stroke: results of the enlimomab acute stroke trial. Neurology 57, 14281434.

Ericsson A, Kovacs KJ, Sawchenko PE (1994) A functional anatomical analysis of central pathways subserving the effects of interleukin-1 on stress-related neuroendocrine neurons. The Journal of neuroscience : the official journal of the Society for Neuroscience 14 (2):897-913

Ershler WB, Keller ET (2000) Age-Associated Increased Interleukin-6 Gene Expression, LateLife Diseases, and Frailty. Annual Review of Medicine 51 (1):245-270. doi:doi:10.1146/annurev.med.51.1.245

European cardiovascular disease statistics. (2008). European cardiovascular disease statistics 2008 European Heart Network, Brussels

Fassbender K, Dempfle CE, Mielke O, Rossol S, Schneider S, Dollman M, Hennerici M (1997) Proinflammatory cytokines: indicators of infection in high-risk patients. The Journal of laboratory and clinical medicine 130 (5):535-539

Fassbender K, Schmidt R, Mossner R, Daffertshofer M, Hennerici M (1994) Pattern of activation of the hypothalamic-pituitary-adrenal axis in acute stroke. Relation to acute confusional state, extent of brain damage, and clinical outcome. Stroke; a journal of cerebral circulation 25 (6):1105-1108

Fieren MWJA (2012) The Local Inflammatory Responses to Infection of the Peritoneal Cavity in Humans: Their Regulation by Cytokines, Macrophages, and Other Leukocytes. Mediators of Inflammation 2012:9. doi:10.1155/2012/976241

Fisher M, Feuerstein G, Howells DW, Hurn PD, Kent TA, Savitz SI, Lo EH (2009) Update of the stroke therapy academic industry roundtable preclinical recommendations. Stroke; a journal of cerebral circulation 40 (6):2244-2250

Fleshner M (2012) Stress-evoked sterile inflammation, danger associated molecular patterns (DAMPs), microbial associated molecular patterns (MAMPs) and the inflammasome. Brain, behavior, and immunity. doi:10.1016/j.bbi.2012.08.012

Fleshner M, Campisi J, Deak T, Greenwood BN, Kintzel JA, Leem TH, Smith TP, Sorensen B (2002) Acute stressor exposure facilitates innate immunity more in physically active than in sedentary rats. American journal of physiology Regulatory, integrative and comparative physiology 282 (6):R1680-1686. doi:10.1152/ajpregu.00661.2001 
Fleshner M, Nguyen KT, Cotter CS, Watkins LR, Maier SF (1998) Acute stressor exposure both suppresses acquired immunity and potentiates innate immunity. Regulatory and Integrative Physiology 275 (3):R870-R878

Frank MG, Thompson BM, Watkins LR, Maier SF (2012) Glucocorticoids mediate stressinduced priming of microglial pro-inflammatory responses. Brain, behavior, and immunity 26 (2):337-345

Friedrichs K, Klinke A, Baldus S (2011) Inflammatory pathways underlying atrial fibrillation. Trends in molecular medicine 17 (10):556-563. doi:10.1016/j.molmed.2011.05.007

Galea J, Armstrong J, Gadsdon P, Holden H, Francis SE, Holt CM (1996) Interleukin-1 $\beta$ in Coronary Arteries of Patients With Ischemic Heart Disease. Arteriosclerosis, Thrombosis, and Vascular Biology 16 (8):1000-1006. doi:10.1161/01.atv.16.8.1000

Garate I, Garcia-Bueno B, Madrigal JL, Caso JR, Alou L, Gomez-Lus ML, Mico JA, Leza JC (2012) Stress-Induced Neuroinflammation: Role of the Toll-like Receptor-4 Pathway. Biological psychiatry. doi:10.1016/j.biopsych.2012.07.005

Garcia JH, Liu KF, Relton JK (1995) Interleukin-1 receptor antagonist decreases the number of necrotic neurons in rats with middle cerebral artery occlusion. Am J Pathol 147 (5):1477-1486

Gerhard A, Neumaier B, Elitok E, Glatting G, Ries V, Tomczak R, Ludolph AC, Reske SN (2000) In vivo imaging of activated microglia using [11C]PK11195 and positron emission tomography in patients after ischemic stroke. Neuroreport 11 (13):29572960

Ghanim H, Aljada A, Hofmeyer D, Syed T, Mohanty P, Dandona P (2004) Circulating mononuclear cells in the obese are in a proinflammatory state. Circulation 110 (12):1564-1571

Gidday JM, Gasche YG, Copin JC, Shah AR, Perez RS, Shapiro SD, Chan PH, Park TS (2005) Leukocyte-derived matrix metalloproteinase-9 mediates blood-brain barrier breakdown and is proinflammatory after transient focal cerebral ischemia. AmJPhysiol Heart CircPhysiol 289 (2):H558-H568

Glowinska-Olszewska B, Urban M (2007) Elevated matrix metalloproteinase 9 and tissue inhibitor of metalloproteinase 1 in obese children and adolescents. Metabolism 56 (6):799-805

Gomez CR, Hirano S, Cutro BT, Birjandi S, Baila H, Nomellini V, Kovacs EJ (2007) Advanced age exacerbates the pulmonary inflammatory response after lipopolysaccharide exposure. Critical Care Medicine 35 (1):246-251

Graebe M, Pedersen SF, Borgwardt L, Hojgaard L, Sillesen H, Kjaer A (2009) Molecular pathology in vulnerable carotid plaques: correlation with [18]-fluorodeoxyglucose positron emission tomography (FDG-PET). European journal of vascular and endovascular surgery : the official journal of the European Society for Vascular Surgery 37 (6):714-721. doi:10.1016/j.ejvs.2008.11.018 
Grau AJ, Buggle F, Heindl S, Steichen-Wiehn C, Banerjee T, Maiwald M, Rohlfs M, Suhr H, Fiehn W, Becher H, et al. (1995) Recent infection as a risk factor for cerebrovascular ischemia. Stroke; a journal of cerebral circulation 26 (3):373-379

Grau AJ, Urbanek C, Palm F (2010) Common infections and the risk of stroke. Nature reviews Neurology 6 (12):681-694. doi:10.1038/nrneurol.2010.163

Greenhalgh AD, Galea J, Denes A, Tyrrell PJ, Rothwell NJ (2010) Rapid brain penetration of interleukin-1 receptor antagonist in rat cerebral ischaemia: pharmacokinetics, distribution, protection. British journal of pharmacology 160 (1):153-159. doi:10.1111/j.1476-5381.2010.00684.x

Gui T, Shimokado A, Sun Y, Akasaka T, Muragaki Y (2012) Diverse Roles of Macrophages in Atherosclerosis: From Inflammatory Biology to Biomarker Discovery. Mediators of Inflammation 2012:14. doi:10.1155/2012/693083

Gustavsson C, Agardh C-D, Zetterqvist AV, Nilsson J, Agardh E, Gomez MF (2010) Vascular Cellular Adhesion Molecule-1 (VCAM-1) Expression in Mice Retinal Vessels Is Affected by Both Hyperglycemia and Hyperlipidemia. PloS one 5 (9):e12699

Haeusler KG, Schmidt WU, Fohring F, Meisel C, Helms T, Jungehulsing GJ, Nolte CH, Schmolke K, Wegner B, Meisel A, Dirnagl U, Villringer A, Volk HD (2008) Cellular immunodepression preceding infectious complications after acute ischemic stroke in humans. Cerebrovasc Dis 25 (1-2):50-58. doi:10.1159/000111499

Hajat C, Heuschmann PU, Coshall C, Padayachee S, Chambers J, Rudd AG, Wolfe CD (2011) Incidence of aetiological subtypes of stroke in a multi-ethnic population based study: the South London Stroke Register. Journal of neurology, neurosurgery, and psychiatry 82 (5):527-533. doi:10.1136/jnnp.2010.222919

Hankey GJ (2006) Potential new risk factors for ischemic stroke: what is their potential? $\begin{array}{llllll}\text { Stroke; a journal of cerebral circulation } 37 & \text { (8):2181-2188. }\end{array}$ doi:10.1161/01.STR.0000229883.72010.e4

Hansson GK, Libby $P$ (2006) The immune response in atherosclerosis: a double-edged sword. Nat Rev Immunol 6 (7):508-519

Hatashita T, Ito M, Miyaoka M, Ishii S (1990) Chronological alterations of regional cerebral blood flow, glucose utilization, and edema formation after focal ischemia in hypertensive and normotensive rats. Significance of hypertension. Advances in neurology 52:29-37

Hazeldine J, Hampson P, Lord JM (2012) Reduced release and binding of perforin at the immunological synapse underlies the age-related decline in natural killer cell cytotoxicity. Aging Cell 11 (5):751-759

Heart Protection Study Collaborative Group JE, Derrick Bennett, Emma Link, Sarah Parish, John Danesh, Jane Armitage, Rory Collins. (2011) C-reactive protein concentration and the vascular benefits of statin therapy: an analysis of 20,536 patients in the Heart Protection Study. Lancet 377:469-476 
Heo JH, Lucero J, Abumiya T, Koziol JA, Copeland BR, del Zoppo GJ (1999) Matrix metalloproteinases increase very early during experimental focal cerebral ischemia. JCerebBlood Flow Metab 19 (6):624-633

Herman JP (2012) Introduction: stress and neurological disease. Experimental neurology 233 (1):1-2. doi:10.1016/j.expneurol.2011.12.041

Horstmann S, Kalb P, Koziol J, Gardner H, Wagner S (2003) Profiles of matrix metalloproteinases, their inhibitors, and laminin in stroke patients: influence of different therapies. Stroke; a journal of cerebral circulation 34 (9):2165-2170

Hug A, Dalpke A, Wieczorek N, Giese T, Lorenz A, Auffarth G, Liesz A, Veltkamp R (2009) Infarct volume is a major determiner of post-stroke immune cell function and susceptibility to infection. Stroke; a journal of cerebral circulation 40 (10):3226-3232. doi:10.1161/STROKEAHA.109.557967

ladecola C, Anrather J (2011) The immunology of stroke: from mechanisms to translation. Nature medicine 17 (7):796-808. doi:10.1038/nm.2399

Jian LK, Rosenberg GA (2005) Matrix metalloproteinases and free radicals in cerebral ischemia. Free RadicBiolMed 39 (1):71-80

Kamezaki Y, Katsuura S, Kuwano Y, Tanahashi T, Rokutan K (2012) Circulating cytokine signatures in healthy medical students exposed to academic examination stress. Psychophysiology 49 (7):991-997

Kammersgaard LP, Jorgensen HS, Reith J, Nakayama H, Houth JG, Weber UJ, Pedersen PM, Olsen TS (2001) Early infection and prognosis after acute stroke: the Copenhagen Stroke Study. Journal of stroke and cerebrovascular diseases : the $\begin{array}{lllll}\text { official journal of National Stroke Association } 10 & \text { (5):217-221. }\end{array}$ doi:10.1053/jscd.2001.30366

Katsnelson M, Rundek T (2011) Obesity paradox and stroke: noticing the (fat) man behind the curtain. Stroke; a journal of cerebral circulation 42 (12):3331-3332

Katzan IL, Cebul RD, Husak SH, Dawson NV, Baker DW (2003) The effect of pneumonia on mortality among patients hospitalized for acute stroke. Neurology 60 (4):620-625

Kim K-A, Gu W, Lee I-A, Joh E-H, Kim D-H (2012) High Fat Diet-Induced Gut Microbiota Exacerbates Inflammation and Obesity in Mice via the TLR4 Signaling Pathway. PloS one 7 (10):e47713

Kleemann R, Zadelaar S, Kooistra T (2008) Cytokines and atherosclerosis: a comprehensive review of studies in mice. Cardiovascular Research 79 (3):360-376. doi:10.1093/cvr/cvn120

Klingenberg R, Hansson GK (2009) Treating inflammation in atherosclerotic cardiovascular disease: emerging therapies. European heart journal 30 (23):2838-2844. doi:10.1093/eurheartj/ehp477

Kovacs KJ, Elenkov IJ (1995) Differential dependence of ACTH secretion induced by various cytokines on the integrity of the paraventricular nucleus. J Neuroendocrinol 7 (1):1523. 
Kozak W, Kozak A, Johnson MH, Elewa HF, Fagan SC (2008) Vascular protection with candesartan after experimental acute stroke in hypertensive rats: a dose-response study. The Journal of pharmacology and experimental therapeutics 326 (3):773-782. doi:10.1124/jpet.108.139618

Krupinski J, Kaluza J, Kumar P, Kumar S, Wang JM (1994) Role of angiogenesis in patients with cerebral ischemic stroke. Stroke; a journal of cerebral circulation 25 (9):17941798

Kumari R, Willing LB, Krady JK, Vannucci SJ, Simpson IA (2007) Impaired wound healing after cerebral hypoxia-ischemia in the diabetic mouse. J CerebBlood Flow Metab 27 (4):710-718

Kumari R, Willing LB, Patel SD, Baskerville KA, Simpson IA (2011) Increased cerebral matrix metalloprotease- 9 activity is associated with compromised recovery in the diabetic $\mathrm{db} / \mathrm{db}$ mouse following a stroke. J Neurochem 119 (5):1029-1040

Kumari R, Willing LB, Patel SD, Krady JK, Zavadoski WJ, Gibbs EM, Vannucci SJ, Simpson IA (2010) The PPAR-gamma agonist, darglitazone, restores acute inflammatory responses to cerebral hypoxia-ischemia in the diabetic ob/ob mouse. J CerebBlood Flow Metab 30 (2):352-360

Kusaka I, Kusaka G, Zhou C, Ishikawa M, Nanda A, Granger DN, Zhang JH, Tang J (2004) Role of $A T 1$ receptors and $\mathrm{NAD}(\mathrm{P}) \mathrm{H}$ oxidase in diabetes-aggravated ischemic brain injury. American journal of physiology Heart and circulatory physiology 286 (6):H2442-2451. doi:10.1152/ajpheart.01169.2003

Ladenvall C, Jood K, Blomstrand C, Nilsson S, Jern C, Ladenvall P (2006) Serum C-reactive protein concentration and genotype in relation to ischemic stroke subtype. Stroke; a $\begin{array}{lllll}\text { journal of } & \text { cerebral } & \text { circulation } & & \end{array}$ doi:10.1161/01.STR.0000231872.86071.68

Laimer M, Kaser S, Kranebitter M, Sandhofer A, Muhlmann G, Schwelberger H, Weiss H, Patsch JR, Ebenbichler CF (2005) Effect of pronounced weight loss on the nontraditional cardiovascular risk marker matrix metalloproteinase- 9 in middle-aged morbidly obese women. IntJObes(Lond) 29 (5):498-501

Langdon KD, Clarke J, Corbett D (2011) Long-term exposure to high fat diet is bad for your brain: exacerbation of focal ischemic brain injury. Neuroscience 182:82-87

Laskowitz DT, Sheng H, Bart RD, Joyner KA, Roses AD, Warner DS (1997) Apolipoprotein Edeficient mice have increased susceptibility to focal cerebral ischemia. Journal of cerebral blood flow and metabolism : official journal of the International Society of Cerebral Blood Flow and Metabolism 17 (7):753-758. doi:10.1097/00004647199707000-00005

Leon B, Lopez-Bravo M, Ardavin C (2007) Monocyte-Derived Dendritic Cells Formed at the Infection Site Control the Induction of Protective $\mathrm{T}$ Helper 1 Responses against Leishmania. Immunity 26 (4):519-531 
Lewis DH, Chan DL, Pinheiro D, Armitage-Chan E, Garden OA (2012) The Immunopathology of Sepsis: Pathogen Recognition, Systemic Inflammation, the Compensatory AntiInflammatory Response, and Regulatory $T$ Cells. Journal of Veterinary Internal Medicine 26 (3):457-482

Li H, Lelliott C, Hakansson P, Ploj K, Tuneld A, Verolin-Johansson M, Benthem L, Carlsson B, Storlien L, MichaÃ«Isson E (2008) Intestinal, adipose, and liver inflammation in dietinduced obese mice. Metabolism 57 (12):1704-1710

Lindsberg PJ, Carpen O, Paetau A, Karjalainen-Lindsberg ML, Kaste M (1996) Endothelial ICAM-1 expression associated with inflammatory cell response in human ischemic stroke. Circulation 94 (5):939-945

Liu F, Yuan R, Benashski SE, McCullough LD (2009) Changes in experimental stroke outcome across the life span. Journal of cerebral blood flow and metabolism : official journal of the International Society of Cerebral Blood Flow and Metabolism 29 (4):792-802. doi:10.1038/jcbfm.2009.5

Liu Y, Liu T, McCarron RM, Spatz M, Feuerstein G, Hallenbeck JM, Siren AL (1996) Evidence for activation of endothelium and monocytes in hypertensive rats. American journal of physiology Heart and circulatory physiology 270 (6):H2125-H2131

Lord JM, Butcher S, Killampali V, Lascelles D, Salmon M (2001) Neutrophil ageing and immunesenescence. Mechanisms of Ageing and Development 122 (14):1521-1535

Macko RF, Ameriso SF, Barndt R, Clough W, Weiner JM, Fisher M (1996) Precipitants of brain infarction. Roles of preceding infection/inflammation and recent psychological stress. Stroke; a journal of cerebral circulation 27 (11):1999-2004

Madrigal JL, Caso JR, de Cristobal J, Cardenas A, Leza JC, Lizasoain I, Lorenzo P, Moro MA (2003) Effect of subacute and chronic immobilisation stress on the outcome of permanent focal cerebral ischaemia in rats. Brain research 979 (1-2):137-145

Mangat R, Su J, Scott PG, Russell JC, Vine DF, Proctor SD (2007) Chylomicron and apoB48 metabolism in the JCR:LA corpulent rat, a model for the metabolic syndrome. Biochemical Society transactions 35 (Pt 3):477-481

Mariotti M, Castiglioni S, Bernardini D, Maier J (2006) Iterleukin 1 alpha is a marker of endothelial cellular senescent. Immunity \& Ageing 3 (1):4

Mariucci G, Taha E, Tantucci M, Spaccatini C, Tozzi A, Ambrosini MV (2011) Intravenous administration of pravastatin immediately after middle cerebral artery occlusion reduces cerebral oedema in spontaneously hypertensive rats. European journal of pharmacology 660 (2-3):381-386. doi:10.1016/j.ejphar.2011.04.002

Markus HS, Hunt B, Palmer K, Enzinger C, Schmidt H, Schmidt R (2005) Markers of endothelial and hemostatic activation and progression of cerebral white matter hyperintensities: longitudinal results of the Austrian Stroke Prevention Study. Stroke; $\begin{array}{lllll}\text { a journal of cerebral circulation } 36 & \text { (7):1410-1414. }\end{array}$ doi:10.1161/01.STR.0000169924.60783.d4 
Marnane M, Merwick A, Sheehan OC, Hannon N, Foran P, Grant T, Dolan E, Moroney J, Murphy S, O'Rourke K, O'Malley K, O'Donohoe M, McDonnell C, Noone I, Barry M, Crowe M, Kavanagh E, O'Connell M, Kelly PJ (2012) Carotid plaque inflammation on 18F-fluorodeoxyglucose positron emission tomography predicts early stroke recurrence. Annals of neurology 71 (5):709-718. doi:10.1002/ana.23553

Marvar PJ, Thabet SR, Guzik TJ, Lob HE, McCann LA, Weyand C, Gordon FJ, Harrison DG (2010) Central and Peripheral Mechanisms of T-Lymphocyte Activation and Vascular Inflammation Produced by Angiotensin II-Induced Hypertension. Circulation Research 107 (2):263-270. doi:10.1161/circresaha.110.217299

Maslanik T, Bernstein-Hanley I, Helwig B, Fleshner M (2012) The impact of acute-stressor exposure on splenic innate immunity: A gene expression analysis. Brain, behavior, and immunity 26 (1):142-149

McColl BW, Allan SM, Rothwell NJ (2009) Systemic infection, inflammation and acute

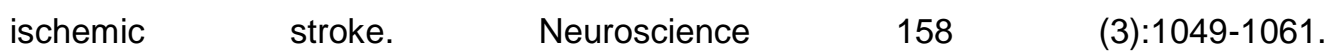
doi:10.1016/j.neuroscience.2008.08.019

McColl BW, Rose N, Robson FH, Rothwell NJ, Lawrence CB (2010a) Increased brain microvascular MMP-9 and incidence of haemorrhagic transformation in obese mice after experimental stroke. Journal of cerebral blood flow and metabolism : official journal of the International Society of Cerebral Blood Flow and Metabolism 30 (2):267-272. doi:10.1038/jcbfm.2009.217

McColl BW, Rose N, Robson FH, Rothwell NJ, Lawrence CB (2010b) Increased brain microvascular MMP-9 and incidence of haemorrhagic transformation in obese mice after experimental stroke. JCerebBlood Flow Metab 30 (2):267-272

McColl BW, Rothwell NJ, Allan SM (2007) Systemic inflammatory stimulus potentiates the acute phase and CXC chemokine responses to experimental stroke and exacerbates brain damage via interleukin-1- and neutrophil-dependent mechanisms. The Journal of neuroscience : the official journal of the Society for Neuroscience 27 (16):44034412. doi:10.1523/JNEUROSCI.5376-06.2007

McColl BW, Rothwell NJ, Allan SM (2008) Systemic inflammation alters the kinetics of cerebrovascular tight junction disruption after experimental stroke in mice. The Journal of neuroscience : the official journal of the Society for Neuroscience 28 (38):9451-9462. doi:10.1523/JNEUROSCI.2674-08.2008

McEwen BS (2000) The neurobiology of stress: from serendipity to clinical relevance. Brain research 886 (1-2):172-189.

Miller GE, Cohen S, Herbert TB (1999) Pathways Linking Major Depression and Immunity in Ambulatory Female Patients. Psychosomatic Medicine 61 (6):850-860

Moreno PR, Falk E, Palacios IF, Newell JB, Fuster V, Fallon JT (1994) Macrophage infiltration in acute coronary syndromes. Implications for plaque rupture. Circulation 90 (2):775778. doi:10.1161/01.cir.90.2.775 
Moreno PR, Murcia AM, Palacios IF, Leon MN, Bernardi VH, Fuster V, Fallon JT (2000) Coronary Composition and Macrophage Infiltration in Atherectomy Specimens From $\begin{array}{lllll}\text { Patients With Diabetes Mellitus. Circulation } 102 & \text { (18):2180-2184. }\end{array}$ doi:10.1161/01.cir.102.18.2180

Morgan TE, Xie Z, Goldsmith S, Yoshida T, Lanzrein AS, Stone D, Rozovsky I, Perry G, Smith MA, Finch CE (1999) The mosaic of brain glial hyperactivity during normal ageing and its attenuation by food restriction. Neuroscience 89 (3):687-699

Moustafa RR, Izquierdo-Garcia D, Fryer TD, Graves MJ, Rudd JH, Gillard JH, Weissberg PL, Baron JC, Warburton EA (2010) Carotid plaque inflammation is associated with cerebral microembolism in patients with recent transient ischemic attack or stroke: a pilot study. Circulation Cardiovascular imaging 3 (5):536-541. doi:10.1161/CIRCIMAGING.110.938225

Muhammad S, Haasbach E, Kotchourko M, Strigli A, Krenz A, Ridder DA, Vogel AB, Marti $\mathrm{HH}$, Al-Abed Y, Planz O, Schwaninger M (2011) Influenza virus infection aggravates stroke outcome. Stroke; a journal of cerebral circulation 42 (3):783-791. doi:10.1161/STROKEAHA.110.596783

Mulcahy NJ, Ross J, Rothwell NJ, Loddick SA (2003) Delayed administration of interleukin-1 receptor antagonist protects against transient cerebral ischaemia in the rat. British journal of pharmacology 140 (3):471-476

Munhoz CD, Garcia-Bueno B, Madrigal JL, Lepsch LB, Scavone C, Leza JC (2008) Stressinduced neuroinflammation: mechanisms and new pharmacological targets. Brazilian journal of medical and biological research $=$ Revista brasileira de pesquisas medicas e biologicas / Sociedade Brasileira de Biofisica [et al] 41 (12):1037-1046

Munhoz CD, Sorrells SF, Caso JR, Scavone C, Sapolsky RM (2010) Glucocorticoids exacerbate lipopolysaccharide-induced signaling in the frontal cortex and hippocampus in a dose-dependent manner. The Journal of neuroscience : the official journal of the Society for Neuroscience 30 (41):13690-13698. doi:10.1523/JNEUROSCI.0303-09.2010

Nagai N, Van Hoef B, Lijnen HR (2007) Plasminogen activator inhibitor-1 contributes to the deleterious effect of obesity on the outcome of thrombotic ischemic stroke in mice. JThrombHaemost 5 (8):1726-1731

Nair A, Bonneau RH (2006) Stress-induced elevation of glucocorticoids increases microglia proliferation through NMDA receptor activation. Journal of neuroimmunology 171 (12):72-85. doi:10.1016/j.jneuroim.2005.09.012

Nakashima Y, Raines EW, Plump AS, Breslow JL, Ross R (1998) Upregulation of VCAM-1 and ICAM-1 at Atherosclerosis-Prone Sites on the Endothelium in the ApoE-Deficient Mouse. Arteriosclerosis, Thrombosis, and Vascular Biology 18 (5):842-851. doi:10.1161/01.atv.18.5.842

Nighoghossian N, Wiart M, Cakmak S, Berthezene Y, Derex L, Cho TH, Nemoz C, Chapuis F, Tisserand GL, Pialat JB, Trouillas P, Froment JC, Hermier M (2007) Inflammatory 
response after ischemic stroke: a USPIO-enhanced MRI study in patients. Stroke; a $\begin{array}{lllll}\text { journal of } & \text { cerebral } & \text { circulation } & \text { (2):303-307. }\end{array}$ doi:10.1161/01.STR.0000254548.30258.f2

O'Donnell MJ, Xavier D, Liu L, Zhang H, Chin SL, Rao-Melacini P, Rangarajan S, Islam S, Pais P, McQueen MJ, Mondo C, Damasceno A, Lopez-Jaramillo P, Hankey GJ, Dans AL, Yusoff K, Truelsen T, Diener H-C, Sacco RL, Ryglewicz D, Czlonkowska A, Weimar C, Wang X, Yusuf S (2010) Risk factors for ischaemic and intracerebral haemorrhagic stroke in 22 countries (the INTERSTROKE study): a case-control study. The Lancet 376 (9735):112-123

Ohmura K, Ishimori N, Ohmura Y, Tokuhara S, Nozawa A, Horii S, Andoh Y, Fujii S, Iwabuchi K, Onoe K, Tsutsui H (2010) Natural Killer T Cells Are Involved in Adipose Tissues Inflammation and Glucose Intolerance in Diet-Induced Obese Mice. Arteriosclerosis, Thrombosis, and Vascular Biology 30 (2):193-199. doi:10.1161/atvbaha.109.198614

Oki I, Nakamura Y, Okamura T, Okayama A, Hayakawa T, Kita Y, Ueshima H (2006) Body mass index and risk of stroke mortality among a random sample of Japanese adults: 19-year follow-up of NIPPON DATA80. CerebrovascDis 22 (5-6):409-415

Olsen TS, Dehlendorff C, Petersen HG, Andersen KK (2008) Body mass index and poststroke mortality. Neuroepidemiology 30 (2):93-100

Olsson T (1990) Urinary free cortisol excretion shortly after ischaemic stroke. Journal of internal medicine 228 (2):177-181

Ovbiagele B, Nguyen-Huynh MN (2011) Stroke epidemiology: advancing our understanding of disease mechanism and therapy. Neurotherapeutics : the journal of the American Society for Experimental NeuroTherapeutics 8 (3):319-329. doi:10.1007/s13311-0110053-1

Packard RR, Lichtman AH, Libby P (2009) Innate and adaptive immunity in atherosclerosis. Seminars in immunopathology 31 (1):5-22. doi:10.1007/s00281-009-0153-8

Paganini-Hill A, Lozano E, Fischberg G, Perez Barreto M, Rajamani K, Ameriso SF, Heseltine PN, Fisher M (2003) Infection and risk of ischemic stroke: differences among stroke subtypes. Stroke; a journal of cerebral circulation 34 (2):452-457

Pan W, Hsuchou H, Jayaram B, Khan RS, Huang EY-K, Wu X, Chen C, Kastin AJ (2012) Leptin action on nonneuronal cells in the CNS: potential clinical applications. Annals of the New York Academy of Sciences 1264 (1):64-71

Pappata S, Levasseur M, Gunn RN, Myers R, Crouzel C, Syrota A, Jones T, Kreutzberg GW, Banati RB (2000) Thalamic microglial activation in ischemic stroke detected in vivo by PET and [11C]PK1195. Neurology 55 (7):1052-1054

Park S, Kim dS, Kang S, Kwon DY (2011) Ischemic hippocampal cell death induces glucose dysregulation by attenuating glucose-stimulated insulin secretion which is exacerbated by a high fat diet. Life Sci 88 (17-18):766-773

Pinteaux E, Rothwell NJ, Boutin H (2006) Neuroprotective actions of endogenous interleukin1 receptor antagonist (IL-1ra) are mediated by glia. Glia 53 (5):551-556 
Pistell PJ, Morrison CD, Gupta S, Knight AG, Keller JN, Ingram DK, Bruce-Keller AJ (2010) Cognitive impairment following high fat diet consumption is associated with brain inflammation. Journal of neuroimmunology 219 (1-2):25-32

Porritt MJ, Chen M, Rewell SS, Dean RG, Burrell LM, Howells DW (2010) ACE inhibition reduces infarction in normotensive but not hypertensive rats: correlation with cortical ACE activity. Journal of cerebral blood flow and metabolism : official journal of the International Society of Cerebral Blood Flow and Metabolism 30 (8):1520-1526. doi:10.1038/jcbfm.2010.57

Pradillo JM, Denes A, Greenhalgh AD, Boutin H, Drake C, McColl BW, Barton E, Proctor SD, Russell JC, Rothwell NJ, Allan SM (2012) Delayed administration of interleukin-1 receptor antagonist reduces ischemic brain damage and inflammation in comorbid rats. Journal of cerebral blood flow and metabolism : official journal of the International Society of Cerebral Blood Flow and Metabolism 32 (9):1810-1819. doi:10.1038/jcbfm.2012.101

Prager M, Turel Z, Speidl WS, Zorn G, Kaun C, Niessner A, Heinze G, Huk I, Maurer G, Huber K, Wojta J (2002) Chlamydia pneumoniae in carotid artery atherosclerosis: a comparison of its presence in atherosclerotic plaque, healthy vessels, and circulating leukocytes from the same individuals. Stroke; a journal of cerebral circulation 33 (12):2756-2761

Price CJ, Menon DK, Peters AM, Ballinger JR, Barber RW, Balan KK, Lynch A, Xuereb JH, Fryer T, Guadagno JV, Warburton EA (2004) Cerebral neutrophil recruitment, histology, and outcome in acute ischemic stroke: an imaging-based study. Stroke; a $\begin{array}{lllll}\text { journal of cerebral } & \text { circulation } & 35 & \text { (7):1659-1664. }\end{array}$ doi:10.1161/01.STR.0000130592.71028.92

Purushothaman KR, Krishnan P, Purushothaman M, Wiley J, Alviar CL, Ruiz FJ, Zubatov Y, Kini AS, Sharma SK, Fuster V, Moreno PR (2012) Expression of angiotensinconverting enzyme 2 and its end product angiotensin 1-7 is increased in diabetic atheroma: implications for inflammation and neovascularization. Cardiovascular Pathology (0)

Radlinska BA, Ghinani SA, Lyon P, Jolly D, Soucy JP, Minuk J, Schirrmacher R, Thiel A (2009) Multimodal microglia imaging of fiber tracts in acute subcortical stroke. Annals of neurology 66 (6):825-832. doi:10.1002/ana.21796

Rallidis LS, Zolindaki MG, Vikelis M, Kaliva K, Papadopoulos C, Kremastinos DT (2009) Elevated soluble intercellular adhesion molecule-1 levels are associated with poor short-term prognosis in middle-aged patients with acute ischaemic stroke. International journal of cardiology 132 (2):216-220. doi:10.1016/j.ijcard.2007.11.031

Ridker PM, Danielson E, Fonseca FA, Genest J, Gotto AM, Jr., Kastelein JJ, Koenig W, Libby P, Lorenzatti AJ, MacFadyen JG, Nordestgaard BG, Shepherd J, Willerson JT, Glynn RJ (2008) Rosuvastatin to prevent vascular events in men and women with elevated 
C-reactive protein. The New England journal of medicine 359 (21):2195-2207. doi:10.1056/NEJMoa0807646

Rizk NN, Myatt-Jones J, Rafols J, Dunbar JC (2007) Insulin like growth factor-1 (IGF-1) decreases ischemia-reperfusion induced apoptosis and necrosis in diabetic rats. Endocrine 31 (1):66-71

Romanic AM, White RF, Arleth AJ, Ohlstein EH, Barone FC (1998) Matrix metalloproteinase expression increases after cerebral focal ischemia in rats: inhibition of matrix metalloproteinase-9 reduces infarct size. Stroke; a journal of cerebral circulation 29 (5):1020-1030

Roquer J, Cuadrado-Godia E, Giralt-Steinthauer E, Jimena S, Jimenez-Conde J, MartinezRodriguez JE, Ois A, Rodriguez-Campello A (2012) Previous infection and stroke: a prospective study. Cerebrovasc Dis 33 (4):310-315. doi:10.1159/000335306

Rosell A, Ortega-Aznar A, Alvarez-Sabin J, Fernandez-Cadenas I, Ribo M, Molina CA, Lo EH, Montaner J (2006) Increased brain expression of matrix metalloproteinase-9 after ischemic and hemorrhagic human stroke. Stroke; a journal of cerebral circulation 37 (6):1399-1406

Rosenberg GA, Estrada EY, Dencoff JE (1998) Matrix metalloproteinases and TIMPs are associated with blood-brain barrier opening after reperfusion in rat brain. Stroke; a journal of cerebral circulation 29 (10):2189-2195

Rudd JH, Narula J, Strauss HW, Virmani R, Machac J, Klimas M, Tahara N, Fuster V, Warburton EA, Fayad ZA, Tawakol AA (2010) Imaging atherosclerotic plaque inflammation by fluorodeoxyglucose with positron emission tomography: ready for prime time? Journal of the American College of Cardiology 55 (23):2527-2535. doi:10.1016/j.jacc.2009.12.061

Ryu WS, Lee SH, Kim CK, Kim BJ, Yoon BW (2011) Body mass index, initial neurological severity and long-term mortality in ischemic stroke. CerebrovascDis 32 (2):170-176

Sacco RL, Benjamin EJ, Broderick JP, Dyken M, Easton JD, Feinberg WM, Goldstein LB, Gorelick PB, Howard G, Kittner SJ, Manolio TA, Whisnant JP, Wolf PA (1997) Risk Factors. Stroke; a journal of cerebral circulation 28 (7):1507-1517. doi:10.1161/01.str.28.7.1507

Sairanen T, Carpen O, Karjalainen-Lindsberg ML, Paetau A, Turpeinen U, Kaste M, Lindsberg PJ (2001) Evolution of cerebral tumor necrosis factor-alpha production during human ischemic stroke. Stroke; a journal of cerebral circulation 32 (8):17501758

Saleh A, Schroeter M, Jonkmanns C, Hartung HP, Modder U, Jander S (2004) In vivo MRI of brain inflammation in human ischaemic stroke. Brain : a journal of neurology $127 \mathrm{Pt}$ 7):1670-1677. doi:10.1093/brain/awh191

Sander D, Poppert H, Sander K, Etgen T (2011) The role of intima-media-thickness, anklebrachial-index and inflammatory biochemical parameters for stroke risk prediction: a systematic review. European Journal of Neurology 19 (4):544-e536 
Sander D, Winbeck K, Klingelhofer J, Etgen T, Conrad B (2004) Progression of early carotid atherosclerosis is only temporarily reduced after antibiotic treatment of Chlamydia

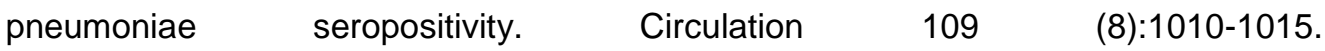
doi:10.1161/01.CIR.0000117232.30832.EC

Sandercock PA, Soane T (2011) Corticosteroids for acute ischaemic stroke. Cochrane Database Syst Rev (9):CD000064. doi:10.1002/14651858.CD000064.pub2

Sanz-Rosa D, Oubina MP, Cediel E, de las Heras N, Vegazo O, Jimenez J, Lahera V, Cachofeiro V (2005) Effect of AT1 receptor antagonism on vascular and circulating inflammatory mediators in SHR: role of $\mathrm{NF}-\mathrm{I}^{\circ} \mathrm{B} / \mathrm{II}^{\circ} \mathrm{B}$ system. Heart and Circulation Physiology 288 (1):H111-H115. doi:10.1152/ajpheart.01061.2003

Scarpellini E, Tack J (2012) Obesity and metabolic syndrome: an inflammatory condition. Digestive diseases (Basel, Switzerland) 30 (2):148-153

Schieffer B, Schieffer E, Hilfiker-Kleiner D, Hilfiker A, Kovanen PT, Kaartinen M, Nussberger J, Harringer W, Drexler H (2000) Expression of Angiotensin II and Interleukin 6 in Human Coronary Atherosclerotic Plaques. Circulation 101 (12):1372-1378. doi:10.1161/01.cir.101.12.1372

Schmid-Schonbein GW, Seiffge D, DeLano FA, Shen K, Zweifach BW (1991) Leukocyte counts and activation in spontaneously hypertensive and normotensive rats. Hypertension 17 (3):323-330. doi:10.1161/01.hyp.17.3.323

Schmidt R, Schmidt H, Pichler M, Enzinger C, Petrovic K, Niederkorn K, Horner S, Ropele S, Watzinger N, Schumacher M, Berghold A, Kostner GM, Fazekas F (2006) C-reactive protein, carotid atherosclerosis, and cerebral small-vessel disease: results of the Austrian Stroke Prevention Study. Stroke; a journal of cerebral circulation 37 (12):2910-2916. doi:10.1161/01.STR.0000248768.40043.f9

Selmeczy Z, Vizi ES, Csoka B, Pacher P, Hasko G (2008) Role of nonsynaptic communication in regulating the immune response. Neurochemistry international 52 (1-2):52-59. doi:10.1016/j.neuint.2007.06.001

Selvamani A, Sohrabji F (2010a) The neurotoxic effects of estrogen on ischemic stroke in older female rats is associated with age-dependent loss of insulin-like growth factor-1. The Journal of neuroscience : the official journal of the Society for Neuroscience 30 (20):6852-6861. doi:10.1523/JNEUROSCI.0761-10.2010

Selvamani A, Sohrabji F (2010b) Reproductive age modulates the impact of focal ischemia on the forebrain as well as the effects of estrogen treatment in female rats. Neurobiology of aging 31 (9):1618-1628. doi:10.1016/j.neurobiolaging.2008.08.014

Shapira S, Sapir M, Wengier A, Grauer E, Kadar T (2002) Aging has a complex effect on a rat model of ischemic stroke. Brain research 925 (2):148-158

Sierra C, Coca A, Schiffrin EL (2011) Vascular mechanisms in the pathogenesis of stroke. Current hypertension reports 13 (3):200-207. doi:10.1007/s11906-011-0195-x

Smith CJ, Emsley HC, Gavin CM, Georgiou RF, Vail A, Barberan EM, del Zoppo GJ, Hallenbeck JM, Rothwell NJ, Hopkins SJ, Tyrrell PJ (2004) Peak plasma interleukin-6 
and other peripheral markers of inflammation in the first week of ischaemic stroke correlate with brain infarct volume, stroke severity and long-term outcome. BMC neurology 4:2. doi:10.1186/1471-2377-4-2

Smith CJ, Emsley HC, Udeh CT, Vail A, Hoadley ME, Rothwell NJ, Tyrrell PJ, Hopkins SJ (2012) Interleukin-1 receptor antagonist reverses stroke-associated peripheral immune suppression. Cytokine 58 (3):384-389. doi:10.1016/j.cyto.2012.02.016

Solana R, Mariani E (2000) NK and NK/T cells in human senescence. Vaccine 18 (16):16131620

Sorrells SF, Caso JR, Munhoz CD, Sapolsky RM (2009) The stressed CNS: when glucocorticoids aggravate inflammation. Neuron 64 (1):33-39. doi:10.1016/j.neuron.2009.09.032

Sorrells SF, Sapolsky RM (2007) An inflammatory review of glucocorticoid actions in the CNS. Brain, behavior, and immunity 21 (3):259-272. doi:10.1016/j.bbi.2006.11.006

Srinivasan D, Yen JH, Joseph DJ, Friedman W (2004) Cell type-specific interleukin-1beta signaling in the CNS. The Journal of neuroscience : the official journal of the Society for Neuroscience 24 (29):6482-6488. doi:10.1523/JNEUROSCI.5712-03.2004

Stelzer I, Zelzer S, Raggam RB, Pruller F, Truschnig-Wilders M, Meinitzer A, Schnedl WJ, Horejsi R, Moller R, Weghuber D, Reeves G, Postolache TT, Mangge H (2012) Link between leptin and interleukin-6 levels in the initial phase of obesity related inflammation. Translational Research 159 (2):118-124

Strazzullo P, D'Elia L, Cairella G, Garbagnati F, Cappuccio FP, Scalfi L (2010) Excess body weight and incidence of stroke: meta-analysis of prospective studies with 2 million participants. Stroke; a journal of cerebral circulation 41 (5):e418-e426

Stroemer RP, Rothwell NJ (1997) Cortical protection by localized striatal injection of IL-1 ra following cerebral ischemia in the rat. Journal of cerebral blood flow and metabolism : official journal of the International Society of Cerebral Blood Flow and Metabolism 17 (6):597-604

Sugama S, Fujita M, Hashimoto M, Conti B (2007) Stress induced morphological microglial activation in the rodent brain: involvement of interleukin-18. Neuroscience 146 (3):1388-1399. doi:10.1016/j.neuroscience.2007.02.043

Sugama S, Takenouchi T, Fujita M, Kitani H, Hashimoto M (2010) Cold stress induced morphological microglial activation and increased IL-1 $\hat{I}^{2}$ expression in astroglial cells in rat brain. Journal of neuroimmunology 233 (1-2):29-36

Sugo N, Hurn PD, Morahan MB, Hattori K, Traystman RJ, DeVries AC (2002) Social stress exacerbates focal cerebral ischemia in mice. Stroke; a journal of cerebral circulation 33 (6):1660-1664

Sun S, Ji Y, Kersten S, Qi L (2012) Mechanisms of inflammatory responses in obese adipose tissue. Annual review of nutrition 32:261-286 
Surtees PG, Wainwright NW, Luben RN, Wareham NJ, Bingham SA, Khaw KT (2008) Psychological distress, major depressive disorder, and risk of stroke. Neurology 70 (10):788-794. doi:10.1212/01.wnl.0000304109.18563.81

Tahara N, Kai H, Ishibashi M, Nakaura H, Kaida H, Baba K, Hayabuchi N, Imaizumi T (2006) Simvastatin attenuates plaque inflammation: evaluation by fluorodeoxyglucose positron emission tomography. Journal of the American College of Cardiology 48 (9):1825-1831. doi:10.1016/j.jacc.2006.03.069

Tarkowski E, Rosengren L, Blomstrand C, Wikkelso C, Jensen C, Ekholm S, Tarkowski A (1995) Early intrathecal production of interleukin-6 predicts the size of brain lesion in stroke. Stroke; a journal of cerebral circulation 26 (8):1393-1398

Tawakol A, Migrino RQ, Bashian GG, Bedri S, Vermylen D, Cury RC, Yates D, LaMuraglia GM, Furie K, Houser S, Gewirtz H, Muller JE, Brady TJ, Fischman AJ (2006) In vivo 18F-fluorodeoxyglucose positron emission tomography imaging provides a noninvasive measure of carotid plaque inflammation in patients. Journal of the American College of Cardiology 48 (9):1818-1824. doi:10.1016/j.jacc.2006.05.076

Terao S, Yilmaz G, Stokes KY, Ishikawa M, Kawase T, Granger DN (2008) Inflammatory and injury responses to ischemic stroke in obese mice. Stroke; a journal of cerebral circulation 39 (3):943-950

Thaler JP, Yi CX, Schur EA, Guyenet SJ, Hwang BH, Dietrich MO, Zhao X, Sarruf DA, Izgur V, Maravilla KR, Nguyen HT, Fischer JD, Matsen ME, Wisse BE, Morton GJ, Horvath TL, Baskin DG, Tschop MH, Schwartz MW (2012) Obesity is associated with hypothalamic injury in rodents and humans. J Clinlnvest 122 (1):153-162

The Emerging Risk Factors Collaboration KS, Di Angelantonio E, Lowe G, Pepys MB, Thompson SG, Collins R, Danesh J. (2010) C-reactive protein concentration and risk of coronary heart disease, stroke, and mortality: an individual participant metaanalysis. Lancet 375:132-140

The Global Burden of Disease WHO. http://wwwwhoint/healthinfo/global burden disease/GBD report 2004update fullpdf

Top Ten Causes of Death WHO http://wwwwhoint/mediacentre/factsheets/fs310 2008pdf

Toung TK, Hurn PD, Traystman RJ, Sieber FE (2000) Estrogen decreases infarct size after temporary focal ischemia in a genetic model of type 1 diabetes mellitus. Stroke; a journal of cerebral circulation 31 (11):2701-2706

Towfighi A, Ovbiagele B (2009) The impact of body mass index on mortality after stroke. Stroke; a journal of cerebral circulation 40 (8):2704-2708

Tureyen K, Bowen K, Liang J, Dempsey RJ, Vemuganti R (2011) Exacerbated brain damage, edema and inflammation in type-2 diabetic mice subjected to focal ischemia. $J$ Neurochem 116 (4):499-507

Tureyen K, Kapadia R, Bowen KK, Satriotomo I, Liang J, Feinstein DL, Vemuganti R (2007) Peroxisome proliferator-activated receptor-gamma agonists induce neuroprotection following transient focal ischemia in normotensive, normoglycemic as well as 
hypertensive and type-2 diabetic rodents. Journal of neurochemistry 101 (1):41-56. doi:10.1111/j.1471-4159.2006.04376.x

Tuttolomondo A, Di Sciacca R, Di Raimondo D, Serio A, D'Aguanno G, La Placa S, Pecoraro R, Arnao V, Marino L, Monaco S, Natale E, Licata G, Pinto A (2009) Plasma levels of inflammatory and thrombotic/fibrinolytic markers in acute ischemic strokes: relationship with TOAST subtype, outcome and infarct site. Journal of neuroimmunology 215 (1-2):84-89. doi:10.1016/j.jneuroim.2009.06.019

Uchida Y, Takeshita K, Yamamoto K, Kikuchi R, Nakayama T, Nomura M, Cheng XW, Egashira K, Matsushita T, Nakamura H, Murohara T (2012) Stress augments insulin resistance and prothrombotic state: role of visceral adipose-derived monocyte chemoattractant protein-1. Diabetes 61 (6):1552-1561. doi:10.2337/db11-0828

Ueland T, Smedbakken LM, Hallen J, Atar D, Januzzi JL, Halvorsen B, Jensen JK, Aukrust P (2012) Soluble CXCL16 and long-term outcome in acute ischemic stroke. Atherosclerosis 220 (1):244-249. doi:10.1016/j.atherosclerosis.2011.10.004

Umemura T, Kawamura T, Umegaki H, Mashita S, Kanai A, Sakakibara T, Hotta N, Sobue G (2011) Endothelial and inflammatory markers in relation to progression of ischaemic cerebral small-vessel disease and cognitive impairment: a 6-year longitudinal study in patients with type 2 diabetes mellitus. Journal of neurology, neurosurgery, and psychiatry 82 (11):1186-1194. doi:10.1136/jnnp.2010.217380

Urra X, Cervera A, Obach V, Climent N, Planas AM, Chamorro A (2009) Monocytes are major players in the prognosis and risk of infection after acute stroke. Stroke; a journal of cerebral circulation 40 (4):1262-1268. doi:10.1161/STROKEAHA.108.532085

van Dijk EJ, Prins ND, Vermeer SE, Vrooman HA, Hofman A, Koudstaal PJ, Breteler MM (2005) C-reactive protein and cerebral small-vessel disease: the Rotterdam Scan Study. Circulation 112 (6):900-905. doi:10.1161/CIRCULATIONAHA.104.506337

Vemmos K, Ntaios G, Spengos K, Savvari P, Vemmou A, Pappa T, Manios E, Georgiopoulos G, Alevizaki M (2011) Association between obesity and mortality after acute first-ever stroke: the obesity-stroke paradox. Stroke; a journal of cerebral circulation 42 (1):3036

Venketasubramanian N, Rother J, Bhatt DL, Pasquet B, Mas JL, Alberts MJ, Hill MD, Aichner F, Steg PG (2011) Two-year vascular event rates in patients with symptomatic cerebrovascular disease: the REACH registry. Cerebrovasc Dis 32 (3):254-260. doi:10.1159/000328650

Vila N, Filella X, Deulofeu R, Ascaso C, Abellana R, Chamorro A (1999) Cytokine-induced inflammation and long-term stroke functional outcome. Journal of the neurological sciences $162(2): 185-188$

Walkey AJ, Wiener RS, Ghobrial JM, Curtis LH, Benjamin EJ (2011) Incident stroke and mortality associated with new-onset atrial fibrillation in patients hospitalized with severe sepsis. JAMA : the journal of the American Medical Association 306 (20):2248-2254. doi:10.1001/jama.2011.1615 
Wang RY, Wang PS, Yang YR (2003) Effect of age in rats following middle cerebral artery occlusion. Gerontology 49 (1):27-32. doi:66505

Wang T, Fu FH, Han B, Zhu M, Yu X, Zhang LM (2009) Aspirin attenuates cerebral ischemic injury in diabetic rats. Experimental and clinical endocrinology \& diabetes : official journal, German Society of Endocrinology [and] German Diabetes Association 117 (4):181-185. doi:10.1055/s-0028-1087210

Wardlaw JM, Murray V, Berge E, del Zoppo G, Sandercock P, Lindley RL, Cohen G (2012) Recombinant tissue plasminogen activator for acute ischaemic stroke: an updated systematic review and meta-analysis. Lancet 379 (9834):2364-2372. doi:10.1016/S0140-6736(12)60738-7

Weimar C, Konig IR, Kraywinkel K, Ziegler A, Diener HC (2004) Age and National Institutes of Health Stroke Scale Score within 6 hours after onset are accurate predictors of outcome after cerebral ischemia: development and external validation of prognostic models. Stroke; a journal of cerebral circulation 35 (1):158-162. doi:10.1161/01.STR.0000106761.94985.8B

Weisberg SP, McCann D, Desai M, Rosenbaum M, Leibel RL, Ferrante AW (2003) Obesity is associated with macrophage accumulation in adipose tissue. The Journal of Clinical Investigation 112 (12):1796-1808

Westendorp WF, Nederkoorn PJ, Vermeij JD, Dijkgraaf MG, van de Beek D (2011) Poststroke infection: a systematic review and meta-analysis. BMC neurology 11:110. doi:10.1186/1471-2377-11-110

Whiteley W, Jackson C, Lewis S, Lowe G, Rumley A, Sandercock P, Wardlaw J, Dennis M, Sudlow C (2009) Inflammatory markers and poor outcome after stroke: a prospective cohort study and systematic review of interleukin-6. PLoS medicine 6 (9):e1000145. doi:10.1371/journal.pmed.1000145

Whitlock G, Lewington S, Sherliker P, Clarke R, Emberson J, Halsey J, Qizilbash N, Collins $R$, Peto $R$ (2009) Body-mass index and cause-specific mortality in 900000 adults: collaborative analyses of 57 prospective studies. Lancet 373 (9669):1083-1096

Winbeck K, Poppert H, Etgen T, Conrad B, Sander D (2002) Prognostic relevance of early serial C-reactive protein measurements after first ischemic stroke. Stroke; a journal of cerebral circulation 33 (10):2459-2464

Wolf PA, D'Agostino RB, O'Neal MA, Sytkowski P, Kase CS, Belanger AJ, Kannel WB (1992) Secular trends in stroke incidence and mortality. The Framingham Study. Stroke; a journal of cerebral circulation 23 (11):1551-1555

Wright CB, Moon Y, Paik MC, Brown TR, Rabbani L, Yoshita M, DeCarli C, Sacco R, Elkind MS (2009) Inflammatory biomarkers of vascular risk as correlates of leukoariosis. $\begin{array}{lllll}\text { Stroke; a journal of cerebral circulation } 40 & \text { (11):3466-3471. }\end{array}$ doi:10.1161/STROKEAHA.109.559567

Yang Y, Santamaria P (2006) Lessons on autoimmune diabetes from animal models. Clinical Science 110 (6):627-639. doi:10.1042/cs20050330 
Yaochite JNU, Caliari-Oliveira C, Davanso MR, Carlos D, Ribeiro Malmegrim KC, Ribeiro de Barros Cardoso C, Ramalho LNZ, Palma PVB, Santana da Silva J, Cunha FQ, Covas DT, Voltarelli JC (2012) Dynamic changes of the Th17/Tc17 and regulatory T cell populations interfere in the experimental autoimmune diabetes pathogenesis. Immunobiology

Ye X, Chopp M, Liu X, Zacharek A, Cui X, Yan T, Roberts C, Chen J (2011) Niaspan reduces high-mobility group box $1 /$ receptor for advanced glycation endproducts after stroke in $\begin{array}{llll}\text { type-1 diabetic } & \text { 190:339-345. }\end{array}$ doi:10.1016/j.neuroscience.2011.06.004

Yu J, Zeng J, Cheung RT, Xiong L, He M, Liang Z, Hong H, Huang R (2009) Intracerebroventricular injection of epidermal growth factor reduces neurological deficit and infarct volume and enhances nestin expression following focal cerebral infarction in adult hypertensive rats. Clinical and experimental pharmacology \& physiology 36 (5-6):539-546. doi:10.1111/j.1440-1681.2008.05105.x

Zaremba J, Skrobanski P, Losy J (2001) Tumour necrosis factor-alpha is increased in the cerebrospinal fluid and serum of ischaemic stroke patients and correlates with the volume of evolving brain infarct. Biomedicine \& pharmacotherapy = Biomedecine \& pharmacotherapie 55 (5):258-263

Zeller JA, Lenz A, Eschenfelder CC, Zunker P, Deuschl G (2005) Platelet-leukocyte interaction and platelet activation in acute stroke with and without preceding infection. $\begin{array}{lllll}\text { Arterioscler Thromb Vasc } & \text { Biol } & 25 & \text { (7):1519-1523. }\end{array}$ doi:10.1161/01.ATV.0000167524.69092.16

Zhai Y, Busuttil RW, Kupiec-Weglinski JW (2011) Liver ischemia and reperfusion injury: new insights into mechanisms of innate-adaptive immune-mediated tissue inflammation. American journal of transplantation : official journal of the American Society of Transplantation and the American Society of Transplant Surgeons 11 (8):1563-1569. doi:10.1111/j.1600-6143.2011.03579.x

Zhang L, Nair A, Krady K, Corpe C, Bonneau RH, Simpson IA, Vannucci SJ (2004) Estrogen stimulates microglia and brain recovery from hypoxia-ischemia in normoglycemic but not diabetic female mice. J Clinlnvest 113 (1):85-95

Zhao BQ, Tejima E, Lo EH (2007) Neurovascular proteases in brain injury, hemorrhage and remodeling after stroke. Stroke; a journal of cerebral circulation 38 (2 Suppl):748-752

Zhou M, Offer A, Yang G, Smith M, Hui G, Whitlock G, Collins R, Huang Z, Peto R, Chen Z (2008) Body mass index, blood pressure, and mortality from stroke: a nationally representative prospective study of 212,000 Chinese men. Stroke; a journal of cerebral circulation 39 (3):753-759

Zhou X, Nicoletti A, Elhage R, Hansson GK (2000) Transfer of CD4+ T Cells Aggravates Atherosclerosis in Immunodeficient Apolipoprotein E Knockout Mice. Circulation 102 (24):2919-2922. doi:10.1161/01.cir.102.24.2919 


\section{Figure and table legends}

Table 1 Comorbidities in stroke: prevalence, relative risk of stroke and inflammatory status in patients and corresponding animal models. Levels of cytokines, chemokines and amount of inflammatory cells are generally elevated in major comorbidities for stroke. Altered inflammatory cell activation is observed in all comorbidities except for stress and age, in which inflammatory cells appear to display reduced activity, although can show excessive activation in response to inflammatory or other challenges. See further explanation in the text. RR-relative risk, ${ }^{a}$ Dependent on time of pre-stroke infection. ${ }^{b}$ Over 45 years. ${ }^{c}$ After the age of 55.

Table 2 Experimental models of major risk factors and their impact on stroke outcome. Note that only inflammatory mediators, or mediators that exert inflammatory/anti-inflammatory properties are shown where appropriate and only mechanisms that have been functionally

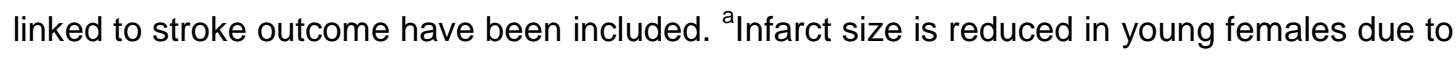
E2. ${ }^{b} \mathrm{E} 2$ increases infarct size if administered to aged female animals. $\alpha 7 \mathrm{nAchR}$ - $\alpha 7$ nicotinic acetylcholine receptor, BBB - blood brain barrier, E2 - 17 $\beta$-estradiol, EGF - epidermal growth factor, HMG-CoA - 3-hydroxy-3-methyl-glutaryl-coenzyme-A, HT - haemorrhagic transformation, IGF-1 - with insulin-like growth factor -1, MCP-1 - monocyte chemoattractant protein-1, PAI-1 - plasminogen activator inhibitor-1, PAMP - pathogen-associated molecular pattern, tPA - tissue plasminogen activator. $\uparrow$ - increase, $\downarrow$-decrease, $\varnothing$ - no change

Fig. 1 Vascular effects of systemic inflammation before and after stroke. Elevated systemic inflammatory burden in major comorbidities for stroke can exert several effects in the CNS, many of which manifest in the vasculature. Altered leukocyte-platelet-endothelial interactions, expression of adhesion molecules, inflammatory cytokines, proteases, endothelial deposition of lipids, inflammatory chemokines and other processes prior to stroke (orange) lead to altered microvascular and glial milieu in the brain, which is likely to impact on the occurrence and progression of acute cerebrovascular events. After stroke (black), primed inflammatory 
cells, altered kinetics of cytokine expression, altered procoagulant-anticoagulant balance, leukocyte recruitment, etc., contribute to BBB injury, glial activation, haemorrhagic complications, which eventually exacerbate brain injury and compromise repair mechanisms. See more detailed explanation and mechanisms in the text. 
Table 1. 


\begin{tabular}{|c|c|c|c|c|c|c|c|}
\hline \multicolumn{5}{|c|}{ HUMAN } & \multicolumn{3}{|c|}{ ANIMAL MODELS } \\
\hline $\begin{array}{l}\text { Prev. } \\
\text { in } \\
\text { stroke }\end{array}$ & $\mathbf{R R}$ & $\begin{array}{c}\text { Infl. } \\
\text { markers }\end{array}$ & Infl. cells & Refs. & $\begin{array}{c}\text { Infl. } \\
\text { markers }\end{array}$ & Infl. cells & Refs. \\
\hline $66 \%$ & $>4$ & $\begin{array}{l}\uparrow \mathrm{IL}-1 \\
\uparrow \mathrm{IL}-6 \\
\uparrow \mathrm{sICAM} \\
\uparrow \mathrm{TF}\end{array}$ & $\begin{array}{l}\uparrow \text { Macrophages } \\
\uparrow T \text { cells (in } \\
\text { atherosclerotic } \\
\text { plaques) }\end{array}$ & $\begin{array}{l}\text { (O'Donnell et al. 2010; Bousser } \\
\text { 2012; Dalekos et al. 1997; Chae } \\
\text { et al. 2001; Celi et al. 2010; } \\
\text { Moreno et al. 1994) }\end{array}$ & $\begin{array}{l}\uparrow \mathrm{IL}-1 \\
\uparrow \mathrm{IL}-6 \\
\uparrow \mathrm{TNF \alpha} \\
\uparrow \mathrm{TF}\end{array}$ & $\begin{array}{l}\uparrow \text { Endothelial } \\
\text { activation } \\
\uparrow \text { Macrophages } \\
\uparrow \text { Leukocytes } \\
\uparrow \text { T cells }\end{array}$ & $\begin{array}{l}\text { (Sanz-Rosa et al. 2005; Celi et } \\
\text { al. 2010; Liu et al. 1996; } \\
\text { Marvar et al. 2010; Schmid- } \\
\text { Schonbein et al. 1991) }\end{array}$ \\
\hline $21 \%$ & $2-4$ & $\begin{array}{l}\uparrow \mathrm{IL}-1 \\
\uparrow \mathrm{IL}-6 \\
\uparrow \mathrm{TNFa}\end{array}$ & $\begin{array}{l}\uparrow \text { Macrophages } \\
\uparrow T \text { cells }\end{array}$ & $\begin{array}{l}\text { (Moreno et al. 2000; O'Donnell et } \\
\text { al. 2010; Bousser 2012; } \\
\text { Purushothaman et al. 2012; } \\
\text { Yaochite et al. 2012; Bradshaw et } \\
\text { al. 2009) }\end{array}$ & $\begin{array}{l}\uparrow \mathrm{IL}-1 \\
\uparrow \mathrm{IL}-6 \\
\uparrow \mathrm{TNF} \alpha\end{array}$ & $\begin{array}{l}\uparrow \text { Endothelial } \\
\text { activation } \\
\uparrow \text { Macrophages } \\
\uparrow \text { T-cells }\end{array}$ & $\begin{array}{l}\text { (Gustavsson et al. 2010; Yang } \\
\text { and Santamaria 2006; } \\
\text { Calderon et al. 2006) }\end{array}$ \\
\hline $42 \%$ & $2-3$ & $\begin{array}{l}\uparrow \mathrm{IL}-1 \\
\uparrow \mathrm{IL}-6 \\
\uparrow \mathrm{TNF}\end{array}$ & $\begin{array}{l}\uparrow \text { Macrophages } \\
\uparrow \mathrm{T} \text { cells (in } \\
\text { atherosclerotic } \\
\text { plaques) }\end{array}$ & $\begin{array}{l}\text { (Galea et al. 1996; Barath et al. } \\
\text { 1990; Schieffer et al. 2000; } \\
\text { Hansson and Libby 2006; } \\
\text { Dziewas et al. 2007; Sander et al. } \\
\text { 2011; Gui et al. 2012) }\end{array}$ & $\begin{array}{l}\uparrow \text { IL-1 } \\
\uparrow \text { IL-6 } \\
\uparrow \text { TNFa } \\
\uparrow \text { IL-4 } \\
\uparrow \text { IFNy }\end{array}$ & $\begin{array}{l}\text { } \uparrow \text { Endothelial } \\
\text { activation } \\
\uparrow \text { Leukocytes } \\
\uparrow \text { T cells } \\
\uparrow \text { Microglial } \\
\text { activation }\end{array}$ & $\begin{array}{l}\text { (Kleemann et al. 2008; } \\
\text { Nakashima et al. 1998; Zhou } \\
\text { et al. 2000; Dong and Wagner } \\
\text { 1998; Drake et al. 2011b) }\end{array}$ \\
\hline $43 \%$ & $<2$ & $\begin{array}{l}\uparrow \mathrm{IL}-1 \\
\uparrow \mathrm{IL}-6 \\
\uparrow \mathrm{TNF \alpha} \\
\uparrow \mathrm{MMPs}\end{array}$ & $\begin{array}{l}\uparrow \text { Macrophages } \\
\uparrow T \text { cells } \\
\uparrow \text { NK cells }\end{array}$ & $\begin{array}{l}\text { (Duffaut et al. 2009; Derosa et al. } \\
\text { 2008b; O'Donnell et al. 2010; } \\
\text { Bousser 2012; Li et al. 2008; } \\
\text { Stelzer et al. 2012; Weisberg et } \\
\text { al. 2003; Ohmura et al. 2010) }\end{array}$ & $\begin{array}{l}\uparrow \mathrm{IL}-1 \\
\uparrow \mathrm{IL}-6 \\
\uparrow \mathrm{TNF} \alpha\end{array}$ & $\begin{array}{l}\uparrow \text { Macrophages } \\
\uparrow \text { Astrocytic } \\
\text { activation }\end{array}$ & $\begin{array}{l}\text { (Kim et al. 2012; Pan et al. } \\
\text { 2012) }\end{array}$ \\
\hline $\begin{array}{l}20- \\
40 \%^{\mathrm{a}}\end{array}$ & $<2$ & $\begin{array}{l}\uparrow \text { IL-1 } \\
\uparrow \text { IL-6 } \\
\uparrow \mathrm{TNFa} \\
\uparrow \mathrm{IFN \gamma}\end{array}$ & $\begin{array}{l}\uparrow \text { Monocytes } \\
\uparrow \text { NK cells }\end{array}$ & $\begin{array}{l}\text { (Bousser 2012; Fieren 2012; } \\
\text { Andaluz-Ojeda et al. 2011; Leon } \\
\text { et al. 2007; Emsley and Hopkins } \\
\text { 2008b) }\end{array}$ & $\begin{array}{l}\uparrow \mathrm{IL}-1 \\
\uparrow \mathrm{IL}-6 \\
\uparrow \mathrm{TNF} \alpha\end{array}$ & $\begin{array}{l}\uparrow \text { Endothelial } \\
\text { activation } \\
\uparrow \text { Neutrophils }\end{array}$ & (Lewis et al. 2012) \\
\hline $20 \%$ & $2-4$ & $\begin{array}{l}\uparrow \mathrm{IL}-1 \\
\uparrow \mathrm{TNF} \alpha \\
\uparrow \mathrm{IL}-4 \\
\uparrow \mathrm{IFN \gamma}\end{array}$ & $\begin{array}{l}\downarrow \text { Macrophage } \\
\text { activation } \\
\downarrow \text { NK activitation }\end{array}$ & $\begin{array}{l}\text { (Kamezaki et al. 2012; Baybutt } \\
\text { and Holsboer 1990; Miller et al. } \\
\text { 1999; Egido et al. 2012; } \\
\text { O'Donnell et al. 2010) }\end{array}$ & $\begin{array}{l}\uparrow \text { IL-1 (in } \\
\text { the brain) } \\
\uparrow \text { CCL20 } \\
\uparrow \text { CXCL5 }\end{array}$ & $\begin{array}{l}\text { Endothelial } \\
\text { disfunction } \\
\downarrow \text { Macrophage } \\
\text { activation } \\
\downarrow \text { T cells } \\
\downarrow \text { Antibodies } \\
\uparrow \text { Glial activation }\end{array}$ & $\begin{array}{l}\text { (Frank et al. 2012; Sugama et } \\
\text { al. 2010; Balkaya et al. 2011b; } \\
\text { Maslanik et al. 2012; Du et al. } \\
\text { 2012; Coe et al. 1988; } \\
\text { Fleshner et al. 1998) }\end{array}$ \\
\hline $86 \%{ }^{b}$ & $\begin{array}{l}\mathrm{x} 2^{\mathrm{C}} \\
\text { every } \\
10 \\
\text { years }\end{array}$ & $\begin{array}{l}\uparrow \mathrm{IL}-1 \\
\uparrow \mathrm{IL}-6 \\
\uparrow \mathrm{TNFa}\end{array}$ & $\begin{array}{l}\uparrow \text { Neutrophils } \\
\uparrow \text { NK (with } \\
\downarrow \text { activity) }\end{array}$ & $\begin{array}{l}\text { (Sacco et al. 1997; Ershler and } \\
\text { Keller 2000; Solana and Mariani } \\
\text { 2000; Lord et al. 2001; Mariotti et } \\
\text { al. 2006) }\end{array}$ & $\begin{array}{l}\uparrow \text { IL-1 (in } \\
\text { infection) } \\
\uparrow \mathrm{CXC} \text { (in } \\
\text { infection) }\end{array}$ & $\begin{array}{l}\downarrow \text { Endothelial } \\
\text { function } \\
\downarrow \text { NK activity } \\
\uparrow \text { Glial activation }\end{array}$ & $\begin{array}{l}\text { (Gomez et al. 2007; Hazeldine } \\
\text { et al. 2012; Morgan et al. 1999; } \\
\text { Brandes et al. 2005) }\end{array}$ \\
\hline
\end{tabular}


Table 2.

\begin{tabular}{|c|c|c|c|c|c|}
\hline $\begin{array}{l}\text { Risk factor / } \\
\text { condition }\end{array}$ & Animal & Gender & Outcome & $\begin{array}{l}\text { Known } \\
\text { mediator } \\
\text { /mechanism }\end{array}$ & Ref. \\
\hline Old age & mouse & male & $\begin{array}{l}\text { Infarct size } \downarrow \text {, edema } \downarrow \text {, BBB } \\
\text { injury } \downarrow \text {, gray matter injury } \downarrow \text {, } \\
\text { white matter injury } \uparrow\end{array}$ & tPA & $\begin{array}{l}\text { (Liu et al. 2009; } \\
\text { Shapira et al. } \\
\text { 2002; Correa et al. } \\
\text { 2011) }\end{array}$ \\
\hline Old age & rat & male & $\begin{array}{l}\text { Infarct size } \varnothing / \uparrow, \text { mortality } \uparrow, \\
\text { brain inflammation } \uparrow\end{array}$ & IL-1 & $\begin{array}{l}\text { (Wang et al. 2003; } \\
\text { Pradillo et al. } \\
\text { 2012) }\end{array}$ \\
\hline Young age $^{a}$ & mouse, rat & female & Infarct size $\downarrow$, edema $\downarrow$ & E2, IGF-1 & $\begin{array}{l}\text { (Liu et al. 2009; } \\
\text { Selvamani and } \\
\text { Sohrabji 2010a, b; } \\
\text { Dubal and Wise } \\
\text { 2001) }\end{array}$ \\
\hline Old age & rat & female & Infarct size $\uparrow$, BBB injury $\uparrow$ & $\mathrm{E} 2^{\mathrm{b}}$ & $\begin{array}{l}\text { (Selvamani and } \\
\text { Sohrabji 2010a, b; } \\
\text { Dinapoli et al. } \\
\text { 2010; DiNapoli et } \\
\text { al. 2008) } \\
\end{array}$ \\
\hline Obesity & $\begin{array}{l}\text { mouse, rat, } \\
\text { gerbil }\end{array}$ & male & $\begin{array}{l}\text { Infarct size } \uparrow, \text { BBB injury } \uparrow \text {, } \\
\mathrm{HT} \uparrow, \text { Inflammatory cells in } \\
\text { the brain } \uparrow\end{array}$ & $\begin{array}{l}\text { PAl-1, MCP-1, } \\
\text { IL-1 }\end{array}$ & $\begin{array}{l}\text { (McColl et al. } \\
\text { 2010a; Langdon } \\
\text { et al. 2011; Nagai } \\
\text { et al. 2007; Park } \\
\text { et al. 2011; Terao } \\
\text { et al. 2008) } \\
\text { (Kumari et al. } \\
\text { 2011; Pradillo et } \\
\text { al. 2012) } \\
\end{array}$ \\
\hline Diabetes & mouse & $\begin{array}{l}\text { male, } \\
\text { female }\end{array}$ & $\begin{array}{l}\text { Infarct size } \uparrow, \text { BBB injury } \uparrow \text {, } \\
\text { Inflammatory cells in the } \\
\text { brain } \uparrow, \text { vascular injury } \uparrow\end{array}$ & $\begin{array}{l}\text { AT(1)-R, } \\
\text { PPARgamma, } \\
\text { IGF-1 }\end{array}$ & $\begin{array}{l}\text { (Kumari et al. } \\
\text { 2011; Bomont and } \\
\text { MacKenzie 1995; } \\
\text { Kusaka et al. } \\
\text { 2004; Tureyen et } \\
\text { al. 2007; Rizk et } \\
\text { al. 2007; Wang et } \\
\text { al. 2009) }\end{array}$ \\
\hline $\begin{array}{l}\text { Atherosclerosis, } \\
\text { hyperlipidaemia }\end{array}$ & mouse, rat & male & $\begin{array}{l}\text { Infarct size } \uparrow, \text { BBB injury } \uparrow \text {, } \\
\text { brain inflammation } \uparrow \text {, brain } \\
\text { edema } \uparrow\end{array}$ & IL-1 & $\begin{array}{l}\text { (Pradillo et al. } \\
\text { 2012; Laskowitz et } \\
\text { al. 1997; EIAli et } \\
\text { al. 2011) }\end{array}$ \\
\hline Hypertension & rat & male & $\begin{array}{l}\text { Infarct size } \uparrow, \text { BBB injury } \uparrow \\
\text { mortality } \uparrow, \text { vascular injury } \uparrow\end{array}$ & $\begin{array}{l}\text { PPARgamma, } \\
\text { Cox-2, TNFa, } \\
\text { EGF, HMG-CoA }\end{array}$ & $\begin{array}{l}\text { (Tureyen et al. } \\
\text { 2007; Hatashita et } \\
\text { al. 1990; Cole et } \\
\text { al. 1993; Dawson } \\
\text { et al. 1996; Porritt } \\
\text { et al. 2010; Yu et } \\
\text { al. 2009; Mariucci } \\
\text { et al. 2011) } \\
\end{array}$ \\
\hline $\begin{array}{l}\text { Infection / } \\
\text { PAMP-induced } \\
\text { systemic } \\
\text { inflammation }\end{array}$ & mouse & male & $\begin{array}{l}\text { Infarct size } \uparrow, \text { BBB injury } \uparrow, \\
\text { mortality } \uparrow, \text { vascular injury } \uparrow \text {, } \\
\text { brain inflammation } \uparrow \text {, } \\
\text { Inflammatory cells in the } \\
\text { brain } \uparrow\end{array}$ & $\begin{array}{l}\text { IL-1, RANTES } \\
\text { (CCL5), MMP-9, } \\
\text { neutrophils, }\end{array}$ & $\begin{array}{l}\text { (McColl et al. } \\
\text { 2007, 2008; } \\
\text { Denes et al. } \\
\text { 2011a; Denes et } \\
\text { al. 2010a; } \\
\text { Muhammad et al. } \\
\text { 2011) }\end{array}$ \\
\hline Stress & rat & male & $\begin{array}{l}\text { Infarct size } \uparrow \text {, behavioral } \\
\text { outcome } \downarrow \text {, endothelial } \\
\text { function } \downarrow \text {, superoxide } \\
\text { production } \uparrow\end{array}$ & $\begin{array}{l}\text { TNFa, } \\
\text { glucocorticoids }\end{array}$ & $\begin{array}{l}\text { (Balkaya et al. } \\
\text { 2011b; Caso et al. } \\
\text { 2009; Madrigal et } \\
\text { al. 2003; Sugo et } \\
\text { al. 2002; Caso et } \\
\text { al. 2006) }\end{array}$ \\
\hline
\end{tabular}


Figure 1.

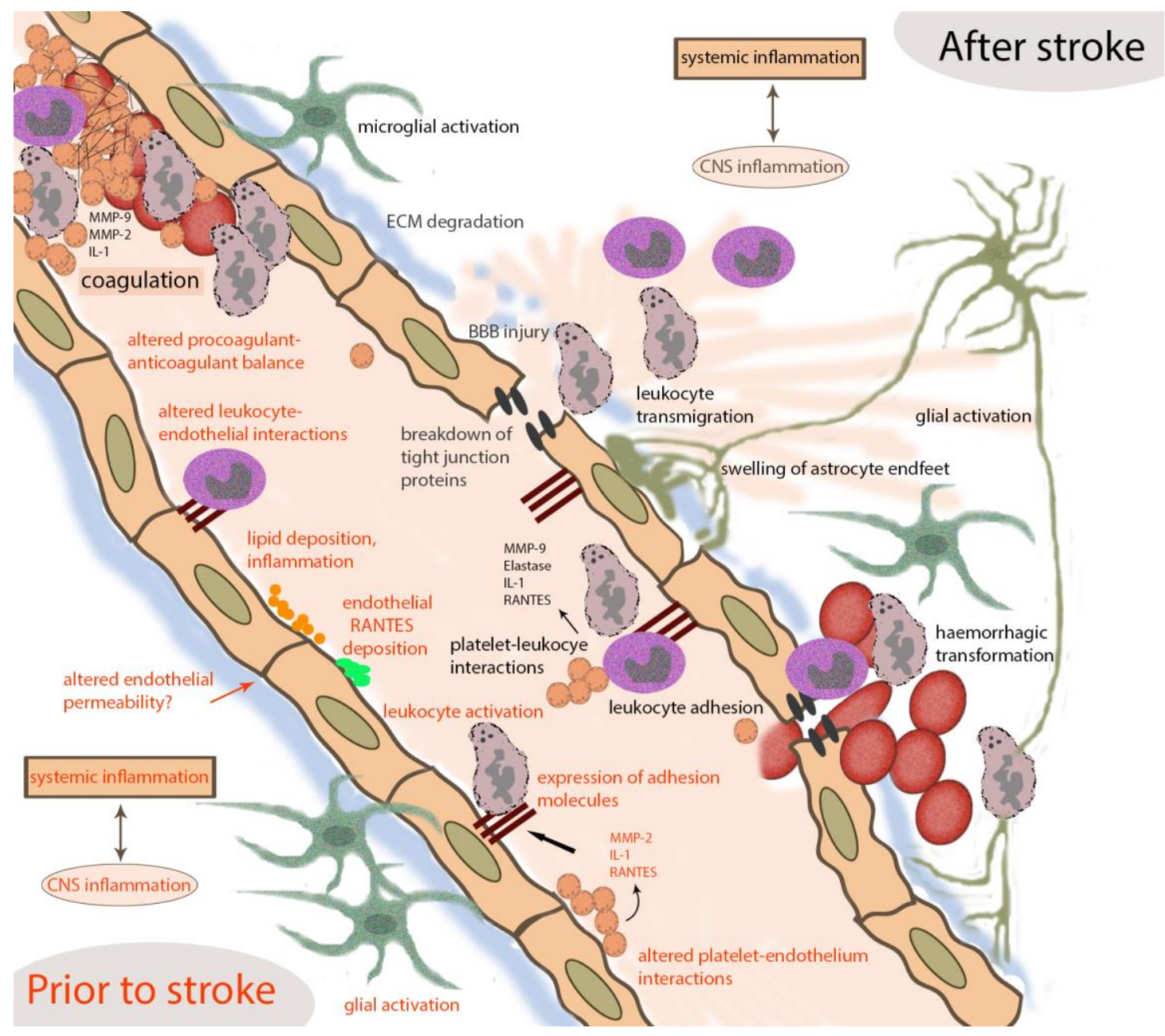

